Cochrane Database of Systematic Reviews

\title{
One dose per day compared to multiple doses per day of gentamicin for treatment of suspected or proven sepsis in neonates (Review)
}

Rao SC, Srinivasjois R, Moon K

Rao SC, Srinivasjois R, Moon K.

One dose per day compared to multiple doses per day of gentamicin for treatment of suspected or proven sepsis in neonates.

Cochrane Database of Systematic Reviews 2016, Issue 12. Art. No.: CD005091.

DOI: 10.1002/14651858.CD005091.pub4.

www.cochranelibrary.com

One dose per day compared to multiple doses per day of gentamicin for treatment of suspected or proven sepsis 
TABLE OF CONTENTS

HEADER 1

ABSTRACT

PLAIN LANGUAGE SUMMARY

SUMMARY OF FINDINGS

BACKGROUND

OBJECTIVES

METHODS

RESULTS

Figure 1.

Figure 2.

Figure 3.

Figure 4.

Figure 5.

Figure 6.

DISCUSSION

AUTHORS' CONCLUSIONS

ACKNOWLEDGEMENTS

REFERENCES

CHARACTERISTICS OF STUDIES

DATA AND ANALYSES

Analysis 1.1. Comparison 1 All studies comparing 'once a day' versus 'multiple doses a day' regimen, Outcome 1 Clearance of proven sepsis.

Analysis 1.2. Comparison 1 All studies comparing 'once a day' versus 'multiple doses a day' regimen, Outcome 2 Failure to achieve peak levels of at least $5 \mathrm{microgram} / \mathrm{ml}$.

Analysis 1.3. Comparison 1 All studies comparing 'once a day' versus 'multiple doses a day' regimen, Outcome 3 Failure to achieve trough levels of <= 2 microgram $/ \mathrm{ml}$.

Analysis 1.4. Comparison 1 All studies comparing 'once a day' versus 'multiple doses a day' regimen, Outcome 4 Ototoxicity. ..

Analysis 1.5. Comparison 1 All studies comparing 'once a day' versus 'multiple doses a day' regimen, Outcome 5 Nephrotoxicity.

Analysis 1.6. Comparison 1 All studies comparing 'once a day' versus 'multiple doses a day' regimen, Outcome 6 Treatment failure.

Analysis 1.7. Comparison 1 All studies comparing 'once a day' versus 'multiple doses a day' regimen, Outcome 7 Actual peak levels $(\mu \mathrm{g} / \mathrm{ml})$.

Analysis 1.8. Comparison 1 All studies comparing 'once a day' versus 'multiple doses a day' regimen, Outcome 8 Actual trough levels $(\mu \mathrm{g} / \mathrm{ml})$..

APPENDICES

WHAT'S NEW

HISTORY

CONTRIBUTIONS OF AUTHORS

DECLARATIONS OF INTEREST

SOURCES OF SUPPORT

DIFFERENCES BETWEEN PROTOCOL AND REVIEW

INDEX TERMS

\section{1}

2

3

5

6

6 
[Intervention Review]

\section{One dose per day compared to multiple doses per day of gentamicin for treatment of suspected or proven sepsis in neonates}

Shripada C Raoํ, Ravisha Srinivasjois², Kwi Moon³

1Centre for Neonatal Research and Education, King Edward Memorial Hospital for Women and Princess Margaret Hospital for Children, Perth, Western Australia, Australia. ${ }^{2}$ Neonatology and Paediatrics, University of Western Australia, Joondalup Health Campus, Joondalup, Australia. ${ }^{3}$ Princess Margaret Hospital for Children, Perth, Australia

Contact address: Shripada C Rao, Centre for Neonatal Research and Education, King Edward Memorial Hospital for Women and Princess Margaret Hospital for Children, Perth, Western Australia, 6008, Australia. Shripada.Rao@health.wa.gov.au.

Editorial group: Cochrane Neonatal Group.

Publication status and date: Edited (no change to conclusions), published in Issue 2, 2017.

Citation: Rao SC, Srinivasjois R, Moon K. One dose per day compared to multiple doses per day of gentamicin for treatment of suspected or proven sepsis in neonates. Cochrane Database of Systematic Reviews 2016, Issue 12. Art. No.: CD005091. DOI: 10.1002/14651858.CD005091.pub4.

Copyright ( 2017 The Cochrane Collaboration. Published by John Wiley \& Sons, Ltd.

\section{A B S T R A C T}

\section{Background}

Animal studies and trials in older children and adults suggest that a 'one dose per day' regimen of gentamicin is superior to a 'multiple doses per day' regimen.

\section{Objectives}

To compare the efficacy and safety of one dose per day compared to multiple doses per day of gentamicin in suspected or proven sepsis in neonates.

\section{Search methods}

Eligible studies were identified by searching the Cochrane Central Register of Controlled Trials (CENTRAL; 2016, Issue 3) in the Cochrane Library (searched 8 April 2016), MEDLINE (1966 to 8 April 2016), Embase (1980 to 8 April 2016), and CINAHL (December 1982 to 8 April 2016 ).

\section{Selection criteria}

All randomised or quasi-randomised controlled trials comparing one dose per day ('once a day') compared to multiple doses per day ('multiple doses a day') of gentamicin to newborn infants.

\section{Data collection and analysis}

Data collection and analysis was performed according to the standards of the Cochrane Neonatal Review Group.

\section{Main results}

Eleven RCTs were included $(\mathrm{N}=574)$ and 28 excluded. All except one study enrolled infants of more than 32 weeks' gestation. Limited information suggested that infants in both 'once a day' as well as 'multiple doses a day' regimens showed adequate clearance of sepsis (typical RR $1.00,95 \% \mathrm{Cl} 0.84$ to 1.19; typical RD $0.00,95 \% \mathrm{Cl}-0.19$ to $0.19 ; 3$ trials; $\mathrm{N}=37$ ). 'Once a day' gentamicin regimen was associated with fewer failures to attain peak level of at least $5 \mu \mathrm{g} / \mathrm{ml}$ (typical RR $0.22,95 \% \mathrm{Cl} 0.11$ to 0.47 ; typical RD $-0.13,95 \% \mathrm{Cl}-0.19$ to -0.08 ; number needed to treat for an additional beneficial outcome (NNTB) $=8 ; 9$ trials; $N=422$ ); and fewer failures to achieve trough levels of $2 \mu \mathrm{g} / \mathrm{ml}$ or less (typical RR $0.38,95 \% \mathrm{Cl} 0.27$ to 0.55 ; typical RD $-0.22,95 \% \mathrm{Cl}-0.29$ to -0.15 ; NNTB $=4 ; 11$ trials; $\mathrm{N}=503$ ). 'Once a day' gentamicin achieved higher peak levels (MD 2.58, $95 \% \mathrm{Cl} 2.26$ to $2.89 ; 10$ trials; $\mathrm{N}=440$ ) and lower trough levels (MD $-0.57,95 \% \mathrm{Cl}-0.69$ to $-0.44 ; 10$ trials; $N=440$ ) than 'multiple doses a day' regimen. There was no significant difference in ototoxicity between two groups 
(typical RR $1.69,95 \% \mathrm{Cl} 0.18$ to 16.25 ; typical RD $0.01,95 \% \mathrm{Cl}-0.04$ to $0.05 ; 5$ trials; $\mathrm{N}=214$ ). Nephrotoxicity was not noted with either of the treatment regimens. Overall, the quality of evidence was considered to be moderate on GRADE analysis, given the small sample size and unclear/high risk of bias in some of the domains in a few of the included studies.

\section{Authors' conclusions}

There is insufficient evidence from the currently available RCTs to conclude whether a 'once a day' or a 'multiple doses a day' regimen of gentamicin is superior in treating proven neonatal sepsis. However, data suggest that pharmacokinetic properties of a 'once a day' gentamicin regimen are superior to a 'multiple doses a day' regimen in that it achieves higher peak levels while avoiding toxic trough levels. There was no change in nephrotoxicity or auditory toxicity. Based on the assessment of pharmacokinetics, a 'once a day regimen' may be superior in treating sepsis in neonates of more than 32 weeks' gestation.

\section{PLAIN LANGUAGE SUMMARY}

\section{Gentamicin dosage in neonates}

Background: Gentamicin is a commonly used antibiotic that is very effective in treating bacterial infections in newborn babies.

Review question: Whether giving the full dose of gentamicin as a single dose per day is better than giving it as multiple small doses in a day in newborn babies.

Study characteristics: Eleven scientific studies were analysed to derive the best available evidence. The majority of the studies included newborn babies born after 32 weeks' gestation. The main outcomes assessed were drug levels in the blood and kidney functions. The search was updated to 29 April 2016.

Key results: Safer and potentially more effective levels of the drug were maintained using a 'one dose per day' treatment schedule. No differences in the risk of adverse effects on the kidney function or hearing were noted between two regimens.

Quality of evidence: The quality was evidence was considered as moderate because the sample size was relatively small and two of the studies were scientifically less robust. 


\section{SUMMARY OF FINDINGS}

\section{Summary of findings for the main comparison.}

One dose per day compared with multiple doses per day of gentamicin for treatment of suspected or proven sepsis in neonates

Patient or population: neonates with suspected or proven sepsis

\section{Settings: neonatal intensive care units}

Intervention: one dose per day gentamicin

Comparison: multiple doses per day gentamicin

\begin{tabular}{|c|c|c|c|c|c|c|}
\hline \multirow[t]{3}{*}{ Outcomes } & \multicolumn{2}{|c|}{$\begin{array}{l}\text { Illustrative comparative risks* } \\
(95 \% \mathrm{Cl})\end{array}$} & \multirow[t]{3}{*}{$\begin{array}{l}\text { Relative effect } \\
(95 \% \mathrm{Cl})\end{array}$} & \multirow{3}{*}{$\begin{array}{l}\text { No of Partici- } \\
\text { pants } \\
\text { (studies) }\end{array}$} & \multirow{3}{*}{$\begin{array}{l}\text { Quality of the } \\
\text { evidence } \\
\text { (GRADE) }\end{array}$} & \multirow[t]{3}{*}{ Comments } \\
\hline & Assumed risk & $\begin{array}{l}\text { Corresponding } \\
\text { risk }\end{array}$ & & & & \\
\hline & $\begin{array}{l}\text { Multiple doses } \\
\text { per day of gen- } \\
\text { tamicin }\end{array}$ & $\begin{array}{l}\text { One dose per } \\
\text { day gentam- } \\
\text { icin }\end{array}$ & & & & \\
\hline $\begin{array}{l}\text { Clearance of proven } \\
\text { sepsis }\end{array}$ & $\begin{array}{l}\text { Actual risk: } 17 \\
\text { per } 17 \\
(1000 \text { per } \\
1000)\end{array}$ & $\begin{array}{l}\text { Actual risk: } 20 \\
\text { per } 20 \\
(1000 \text { per } \\
1000)\end{array}$ & $\begin{array}{l}\mathbf{R R} \mathbf{1}(0.84 \text { to } \\
1.19)\end{array}$ & $\begin{array}{l}37 \\
\text { (3 studies) }\end{array}$ & $\begin{array}{l}\oplus \odot \odot \odot \\
\text { very low }\end{array}$ & $\begin{array}{l}\text { Very small sample size, high risk of bias in the } \\
\text { domain of completeness of follow-up in } 2 \text { stud- } \\
\text { ies, high risk of bias for random sequence gen- } \\
\text { eration and allocation concealment in one } \\
\text { study. }\end{array}$ \\
\hline $\begin{array}{l}\text { Failure to } \\
\text { achieve peak levels } \\
\text { of at least } 5 \text { micro- } \\
\text { gram/ml } \\
\text { (measured } 0.5 \text { to one } \\
\text { hour after administra- } \\
\text { tion of any dose of gen- } \\
\text { tamicin) }\end{array}$ & $\begin{array}{l}\text { Actual risk: } 35 \\
\text { per } 214 \\
(164 \text { per } 1000)\end{array}$ & $\begin{array}{l}\text { Actual risk: } \\
6 \text { per } 208 \\
(29 \text { per } 1000)\end{array}$ & $\begin{array}{l}\operatorname{RR} 0.22(0.11 \\
\text { to } 0.47)\end{array}$ & $\begin{array}{l}422 \\
\text { (9 studies) }\end{array}$ & $\begin{array}{l}\oplus \oplus \oplus \ominus \\
\text { moderate }\end{array}$ & $\begin{array}{l}\text { Moderate sample size, high risk of selection } \\
\text { bias in two studies; high risk of attrition bias in } \\
3 \text { studies. } \\
\text { Narrow Cls around the effect size, very low P } \\
\text { value for effect size } \\
\text { estimate, no statistical heterogeneity }\end{array}$ \\
\hline $\begin{array}{l}\text { Nephrotoxicity } \\
\text { (End of study period or } \\
\text { before discharge) }\end{array}$ & See comment & See comment & Not estimable & $\begin{array}{l}348 \\
\text { (8 studies) }\end{array}$ & See comment & $\begin{array}{l}\text { None of the study infants developed nephro- } \\
\text { toxicity. }\end{array}$ \\
\hline
\end{tabular}




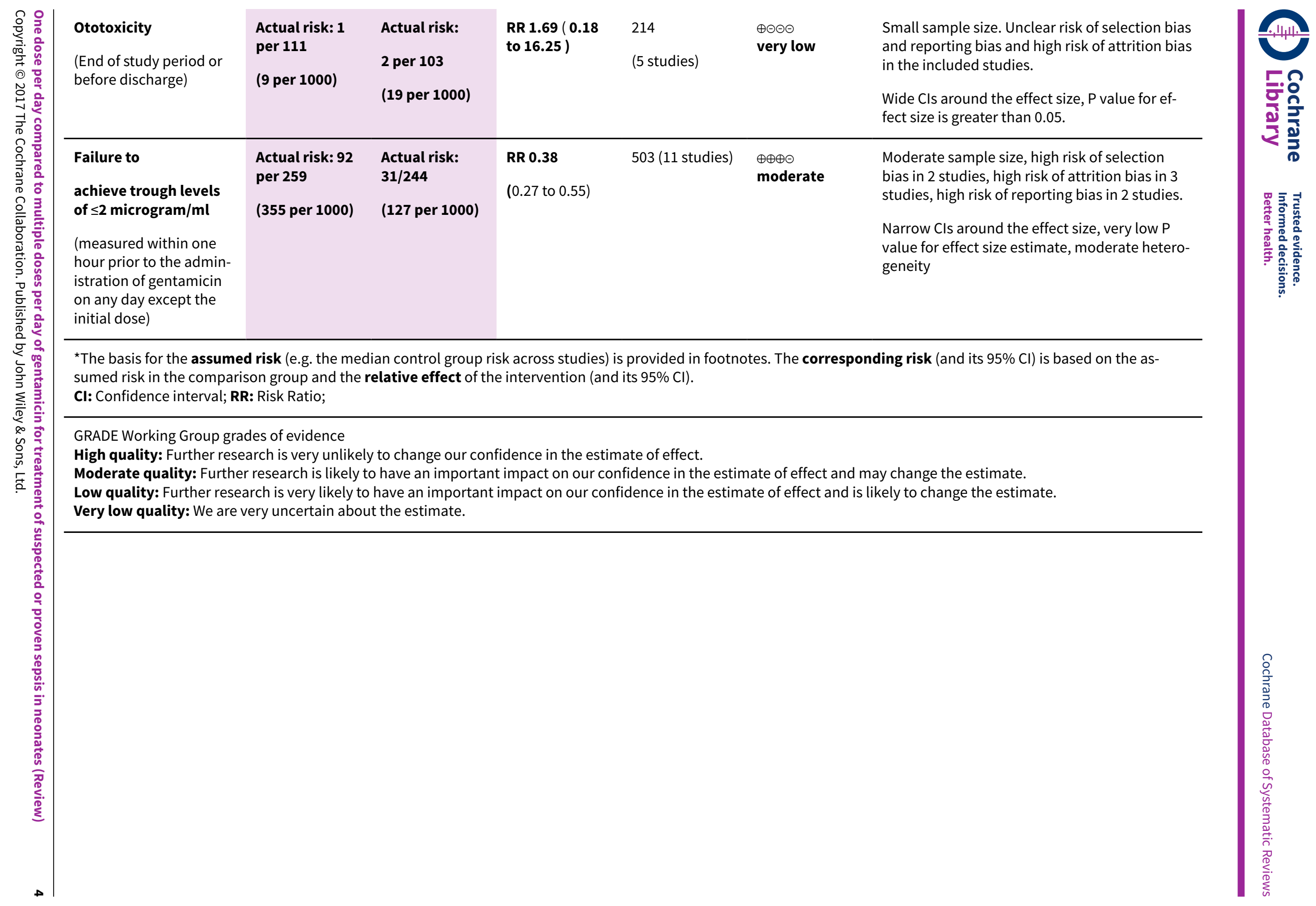




\section{B A C K G R O U N D}

\section{Description of the condition}

Gentamicin, an aminoglycoside antibiotic, is widely used in the treatment of suspected or proven bacterial sepsis in newborn infants. It is rapidly bactericidal. Combined with betalactam antibiotics, it provides synergistic activity against the most commonly encountered pathogens in the neonatal period (Chattopadhyay 2002). Potential ototoxicity and nephrotoxicity has been linked to the drug levels in plasma. Higher trough concentrations are associated with drug toxicity (Swan 1997); and lower peak levels are associated with lesser efficacy (Kovarik 1989; Chambers 2001). The bactericidal effect of gentamicin is concentration dependent; the higher the concentration, the greater the bactericidal effect. Generally accepted peak concentrations are 5 to $10 \mu \mathrm{g} / \mathrm{ml}$. It has been suggested that even higher peak levels (e.g. $25 \mu \mathrm{g}$ per $\mathrm{ml}$ ) do not increase the risk of toxicity (Chambers 2001). It is also suggested that the trough concentrations should be less than 1 to $2 \mu \mathrm{g} / \mathrm{ml}$ to minimise the toxic effects (Chambers 2001). Increasing the interval between doses has the potential to maintain maximal bactericidal activity, while minimizing the side effects.

\section{Description of the intervention}

Several concepts support the benefit of a treatment regime that administers one dose per day ('once a day' dose) of gentamicin (Miron 2003).

1. Gentamicin exhibits a concentration-dependent bactericidal effect in which a positive linear relationship exists between the peak minimum inhibitory concentration (MIC) ratio and bactericidal response.

2. Gentamicin exhibits the post-antibiotic effect (PAE). The PAE is a period during which the antibiotic continues to suppress bacterial growth despite serum concentrations below the MIC (Kahlmeter 1984; Chambers 2001). A prolonged PAE requires high peak concentrations and is associated with better clinical response. Because a 'once a day' dose produces higher peak drug concentrations, it results in a prolonged PAE (Craig 1995).

3. One of the first steps in the uptake of aminoglycoside into sites of toxicity is their binding to the brush borders of renal cells and to the cochlea and vestibular membranes. Uptake by these tissues is more efficient with low sustained concentrations compared to high intermittent levels. Animal models suggest that uptake of gentamicin in the renal cortex and perilymph is a saturable process that is relatively unaffected by drug concentration; transient high peak levels do not lead to excessive drug accumulation (Giuliano 1986; Verpooten 1989; Beaubien 1991). 'Once a day' dosing of aminoglycoside has been shown to be less toxic and more efficacious than more frequent dosing in animal models and observational studies in human neonates (Craig 1995; Darmstadt 2007; Darmstadt 2008; Thingvoll 2008; Begg 2009; Hagen 2009).

4. Adaptive resistance is thought to occur after continuous exposure of bacteria to antibiotic concentrations that are less than the MIC (Lacy 1998). 'Once a day' dosing may help to avoid the development of resistance by achieving a higher bacterial kill initially, thereby decreasing the length of time viable bacteria are in contact with the drug.

5. Neonates, especially sick infants, have low glomerular filtration rate (Aperia 1981; Vanpée 1993; Sonntag 1996; Gallini 2000), which leads to slower clearance and higher volume of distribution of drugs like gentamicin (Nielsen 2009). 'Once a day' dosing, by providing more time for clearance, may avoid the toxic effects of gentamicin due to slower clearance (Begg 2009).

6. Pharmacokinetics of drugs in neonates are unique and greatly influenced by gestational age and birth weight, postnatal age, postconceptional age and renal function (Nielsen 2009; Pacifici 2009; Serane 2009). It may be ideal to use customised dosing for infants based on the gentamicin pharmacokinetics in each infant (Touw 2009). However, this involves frequent measurement of serum gentamicin levels and rewriting of the medication orders with the potential for prescription errors. The majority of the use of gentamicin in the neonatal population is for the treatment of infants with risk factors for sepsis pending culture results for a short period of 48 to 72 hours. If a 'once a day' regimen attains adequate peak levels while avoiding toxic trough levels, then frequent measurement of serum gentamicin levels may not be necessary in these short ( 72 hour) 'rule out sepsis' courses. This would significantly reduce the hospital cost associated with gentamicin therapy (Nicolau 1996; Hitt 1997; Thureen 1999).

\section{How the intervention might work}

Meta analyses of studies in adults have consistently shown that once-daily dosing of aminoglycoside including gentamicin is as effective as multiple daily dosing, with similar or lesser risk of nephrotoxicity and ototoxicity (Barza 1996; Munckhof 1996; Ali 1997; Bailey 1997; Hatala 1997).

A systematic review of similar studies in children and infants concluded that a 'once a day' regimen is more efficacious and has no higher toxicity compared with multiple daily dosing (Miron 2001). A meta-analysis of extended interval aminoglycoside dosing (the dose is higher and administered less frequently than in a traditional dosing regime) in children reported that an extendeddose aminoglycoside regimen provided similar or potentially improved efficacy and safety, compared to a 'multiple doses a day' regimen (Contopoulos-loannidis 2004). A total of 24 studies in paediatric populations up to 20 years of age, including six studies in neonatal populations, were included in their review. Five neonatal studies used gentamicin and one study used amikacin.

Some reports suggest that a 'multiple doses a day' regimen results in subtherapeutic levels and the new practice of extended dosage schedules achieved safe and adequate levels (Bajaj 2004; Darmstadt 2008; Begg 2009; Hagen 2009). It has also been suggested that a dose interval of more than 24 hours is less likely to produce toxic trough levels in preterm neonates (Langlass 1999; Gonzalez Santacruz M 2008; Thingvoll 2008).

\section{Why it is important to do this review}

Despite this information, the appropriate dose interval for gentamicin in neonates is still a matter of debate. Caution has been expressed against the use of a 'once a day' dose of gentamicin in neonatal infections (Chambers 2001). This approach has yet to become standard practice in most paediatric hospitals (Knoderer 2003). A random survey of acute care hospitals in the USA in 1993 found that extended interval aminoglycoside dosing was not practised in neonates, whereas, in 1998, $11.3 \%$ of the hospitals were using extended interval dosing (Chuck 2000). 
In this review, we compared 'one dose per day' versus 'multiple doses per day' of gentamicin in neonates with suspected or proven sepsis.

\section{OB JECTIVES}

To compare the efficacy and safety of one dose per day to multiple doses per day of gentamicin in suspected or proven sepsis in neonates.

Subgroup analysis was performed according to:

1. gestation: less than 32 weeks and 32 weeks or more;

2. suspected or proven sepsis;

3. intramuscular or intravenous administration;

4. use of loading dose.

\section{METHODS}

\section{Criteria for considering studies for this review}

\section{Types of studies}

Randomised and quasi-randomised controlled trials.

\section{Types of participants}

Newborn infants ( $\leq 28$ days after birth) with suspected or proven sepsis commenced on gentamicin. Suspected sepsis was defined as any condition in the neonate which led to the commencement of antibiotics. Proven sepsis was defined as a clinical condition necessitating use of antibiotics and presence of positive blood/ body fluid or tissue cultures.

\section{Types of interventions}

One dose per day ('once a day') compared to multiple doses per day ('multiple doses a day') of gentamicin.

Studies comparing extended dose regimens such as dosing once in 36 to 48 hours versus 'once a day' dosing were not included.

Studies comparing regimens with or without loading dosage were not included. If a trial used a loading dose of gentamicin in both groups, it was included.

Since gentamicin is almost always used along with a second antibiotic, studies which used the same second antibiotic in both groups were included.

Studies using gentamicin either intramuscularly or intravenously were included provided both study and control groups were administered gentamicin by the same route.

If a study used a different second antibiotic along with gentamicin in the study and control groups, it was excluded.

A difference of up to $25 \%$ while calculating the total daily dose was allowed between 'once a day' and 'multiple doses a day' regimens.

\section{Types of outcome measures}

\section{Primary outcomes}

1. Clinical efficacy: clearance of proven sepsis defined as negative blood or other body fluid cultures without the need for a change in antibiotics.
2. Pharmacokinetic efficacy:

a. Failure to reach adequate peak levels of at least $5 \mu \mathrm{g} / \mathrm{ml}$. Peak level was defined as the level measured 0.5 to one hour after administration of any dose of gentamicin on any day during the study period.

b. Failure to avoid toxic trough levels of $>2 \mu \mathrm{g} / \mathrm{ml}$. The trough level was defined as the level measured within one hour prior to the administration of gentamicin on any day during the study period (except the initial dose).

\section{Secondary outcomes}

1. Ototoxicity (examination could be performed at the end of the study period or before discharge with or without baseline testing):

a. Auditory: defined as abnormality in pure tone audiometry or brain-stem evoked auditory response or otoacoustic emission or any other validated hearing test.

b. Vestibular: defined as abnormality in electronystagmography or any other validated vestibular function test.

2. Nephrotoxicity (examination could be performed at the end of the study period or before discharge with or without baseline testing):

a. Primary: any increase in serum creatinine levels or decrease in creatinine clearance, with thresholds as defined in each study.

b. Secondary: urinary excretion of proteins (retinal binding protein, beta-2 microglobulin, Clara cell protein, microalbumin, N-Acetyl-Beta-D-glucosaminidase, alkaline phosphatase, alanine aminopeptidase, or gamma-glutamyl transferase, cystatin C) or phospholipids.

3. Treatment failure: persistent positive blood/body fluid or tissue cultures which lead to any modification of the assigned antibiotic dosing or addition of new antibiotic.

4. Actual peak levels (mean and SD) attained $(\mu \mathrm{g} / \mathrm{ml})$ : peak levels were defined as levels measured at 0.5 to 1 hour after a dose of gentamicin.

5. Actual trough levels (mean and SD) attained $(\mu \mathrm{g} / \mathrm{ml})$ : trough levels were defined as levels measured within one hour prior to giving any dose of gentamicin (except the initial dose).

\section{Search methods for identification of studies}

\section{Electronic searches}

We used the standard search strategy of the Cochrane Neonatal Review Group. This included electronic searches of the Cochrane Central Register of Controlled Trials (CENTRAL; 2016, Issue 3) in the Cochrane Library (searched 8 April 2016), MEDLINE (1966 to 8 April 2016), Embase (1980 to 8 April 2016) and CINAHL (1982 to 8 April 2016) and previous reviews including cross-references. Abstracts of Pediatric Academic Societies meetings (1995 to 2016) were also searched. MEDLINE and Embase were searched for relevant articles using the following $\mathrm{MeSH}$ terms or text words: (Gentamicin/OR aminoglycoside) AND (sepsis OR septicaemia OR septicemia) AND (infant, newborn/OR infant, low birth weight/ OR infant, very low birth weight/OR infant, premature/OR Infant, Premature, Diseases) OR (neonate: OR prematur ${ }^{\star}$ : OR newborn) AND (clinical trial OR Randomised Controlled Trials). Reference lists of published narrative and systematic reviews were also reviewed. No language restrictions were applied. 


\section{Searching other resources}

We searched clinical trials' registries for ongoing or recently completed trials (clinicaltrials.gov; controlled-trials.com; and who.int/ictrp). We also searched reference lists of identified articles.

\section{Data collection and analysis}

We used the standard methods of the Cochrane Neonatal Review Group.

\section{Selection of studies}

Two review authors independently assessed the eligibility of studies for inclusion.

\section{Data extraction and management}

We used a data collection form to aid extraction of relevant information and data from each included study. Two review authors extracted the data separately, compared data, and resolved differences by consensus. Any disagreements were resolved by consultation with the third review author.

We contacted the authors of all studies to clarify reported data or provide additional data and information including details of methodology. They were sent a standardised table and asked to provide missing data not included in their article if it was available. Skopnik 1992, Krishnan 1997, de Alba Romero 1998, Thureen 1999, Chotigeat 2001, Hagan 2002, Miron 2003 and Kosalaraksa 2004 provided additional information, clarified existing data and also clarified methodology of studies. Hayani 1997, Solomon 1999 and Agarwal 2002 were contacted initially by e-mail and subsequently by post four weeks later, but did not respond.

\section{Assessment of risk of bias in included studies}

The criteria and standard methods of the Cochrane Neonatal Review Group were used to assess the methodological quality of the included trials. Risk of bias of the included trials was evaluated in terms of adequacy of sequence generation, allocation concealment, blinding of parents or caregivers and assessors to intervention, and completeness of follow-up in all randomised individuals. This was defined as 'yes', 'no' or 'not clear' for each category. Differences in opinion were resolved after discussion among all three reviewers. See Appendix 1 for the complete 'Risk of bias' tool.

\section{Measures of treatment effect}

Statistical analyses were performed using Review Manager software. We analysed categorical data using relative risk (RR), risk difference $(\mathrm{RD})$ and the number needed to treat for an additional beneficial outcome (NNTB). Continuous data were compared using mean difference (MD). We have reported the $95 \%$ confidence interval $(\mathrm{Cl})$ on all estimates.

\section{Unit of analysis issues}

If available, we planned to combine results from cluster trials with other trials using generic inverse variance methods.

\section{Dealing with missing data}

If participant dropout led to missing data then we planned to conduct an intention-to-treat analysis. We endeavoured to obtain missing data from the trial authors.

\section{Assessment of heterogeneity}

Statistical heterogeneity was assessed using the $\mathrm{I}^{2}$ statistic. As per the Cochrane guidelines, the $\mathrm{I}^{2}$ statistic was interpreted as follows:

- $0 \%$ to $40 \%$ : might not be important

- $30 \%$ to $60 \%$ : may represent moderate heterogeneity

- $50 \%$ to $90 \%$ : may represent substantial heterogeneity

- $75 \%$ to $100 \%$ : considerable heterogeneity

\section{Data synthesis}

Effect size was expressed as relative risk (RR), risk difference (RD) and $95 \%$ confidence intervals (Cls) for categorical data, and mean difference (MD) and $95 \% \mathrm{Cl}$ for continuous data. The fixed-effect model was used for meta-analysis. Change scores of auditory and vestibular tests and tests for nephrotoxicity were planned to be meta-analysed separately from the final value scores. For significant differences NNTB based on 1/RD was calculated.

\section{Quality of evidence}

We assessed the quality of evidence for the main comparison at the outcome level using the GRADE approach (Guyatt 2011a). This methodological approach considers evidence from randomised controlled trials as high quality that may be downgraded based on consideration of any of five areas: design (risk of bias), consistency across studies, directness of the evidence, precision of estimates and presence of publication bias (Guyatt 2011a). The GRADE approach results in an assessment of the quality of a body of evidence in one of four grades: 1) High: We are very confident that the true effect lies close to that of the estimate of the effect; 2) Moderate: We are moderately confident in the effect estimate: The true effect is likely to be close to the estimate of the effect, but there is a possibility that it is substantially different; 3 ) Low: Our confidence in the effect estimate is limited: The true effect may be substantially different from the estimate of the effect; 4) Very Low: We have very little confidence in the effect estimate: The true effect is likely to be substantially different from the estimate of effect (Schünemann 2013).

The review authors independently assessed the quality of the evidence found for outcomes that were considered as critical for clinical decision making. These outcomes included: clearance of proven sepsis, failure to achieve peak level of at least $5 \mu \mathrm{g} / \mathrm{ml}$, failure to achieve trough levels of $2 \mu \mathrm{g} / \mathrm{ml}$ or less, ototoxicity and nephrotoxicity.

In cases where we considered the risk of bias arising from inadequate concealment of allocation, randomised assignment, complete follow-up or blinded outcome assessment reduced our confidence in the effect estimates, we downgraded the quality of evidence accordingly (Guyatt 2011b). We evaluated consistency by similarity of point estimates, extent of overlap of confidence intervals and statistical criteria including measurement of heterogeneity $\left(I^{2}\right)$. We downgraded the quality of evidence when large and unexplained inconsistency across studies' results was present (i.e. some studies suggest important benefit and others 
no effect or harm without a clinical explanation) (Guyatt 2011d). Precision was assessed based on the width of the $95 \%$ confidence interval $(\mathrm{Cl})$ and by calculating the optimal information size (OIS). If the total number of patients included in the pooled effect estimation was less than the number of patients generated by a conventional sample size calculation for a single adequately powered trial, we considered downrating for imprecision (Guyatt 2011c). When trials were conducted in populations other than the target population, we downgraded the quality of evidence because of indirectness (Guyatt 2011e).

We entered data (i.e. pooled estimates of the effects and corresponding 95\% Cls) and explicit judgements for each of the above aspects assessed into the Guideline Development Tool, the software used to create 'Summary of findings' tables (GRADEpro). We explained all judgements involving the assessment of the study characteristics described above in footnotes or comments in the 'Summary of findings' table.

\section{Subgroup analysis and investigation of heterogeneity}

Subgroup analysis was performed according to:

1. gestation: $<32$ weeks and $\geq 32$ weeks;
2. suspected or proven sepsis;

3. intramuscular or intravenous administration;

4. use of loading dose.

\section{Sensitivity analysis}

We planned to conduct sensitivity analyses by excluding studies where trial participants were of extremely low gestation age because these infants may require even further extended dosing intervals for gentamicin (up to 36 to 48 hours).

\section{RE S U L T S}

\section{Description of studies}

For a full description of each trial, see the Characteristics of included studies section.

\section{Results of the search}

Thirty-nine studies were identified as potentially eligible. Twentyeight were excluded and 11 studies were included in the review; (see Figure 1). 
Figure 1. Study flow diagram: review update

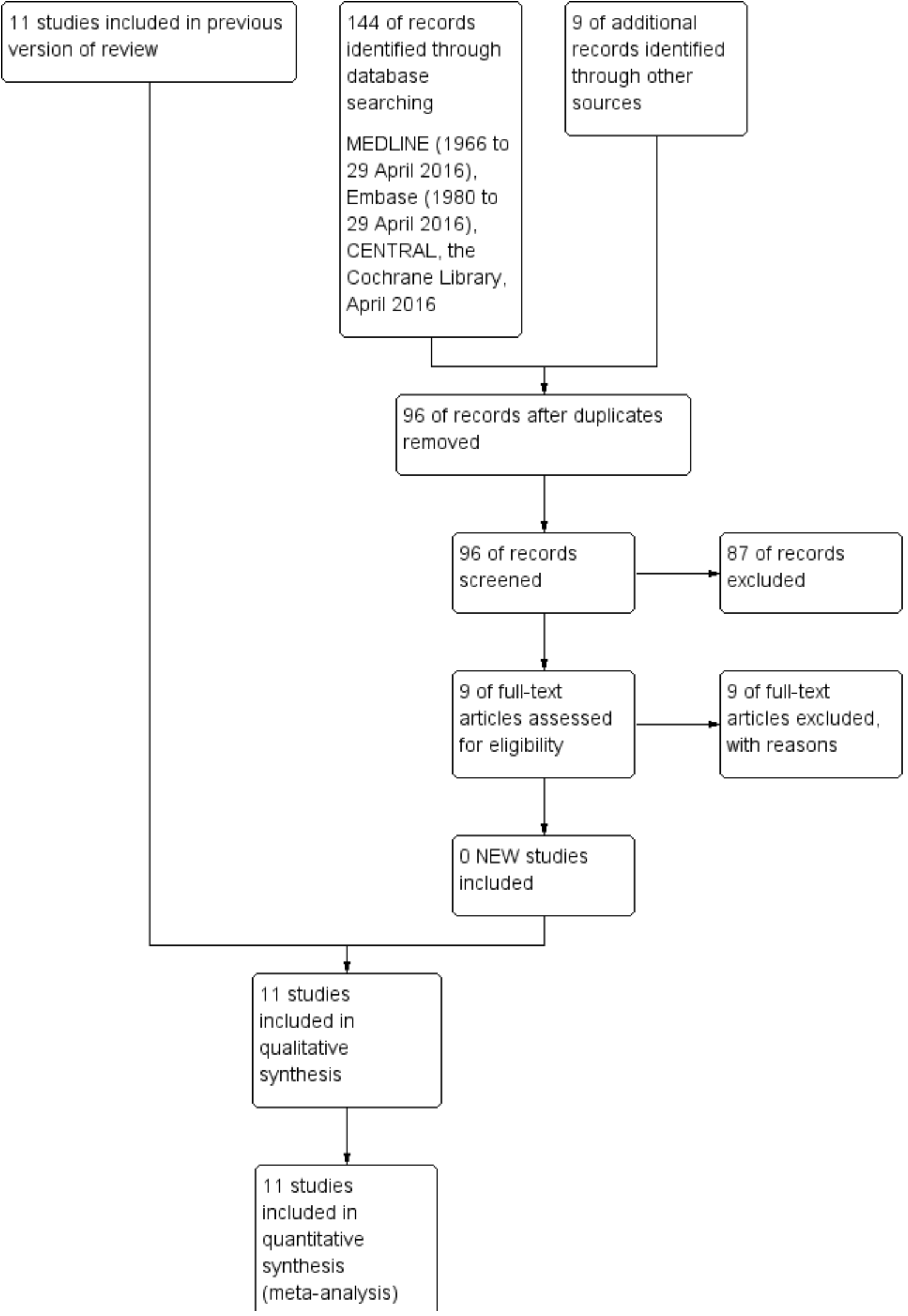


Figure 1. (Continued)

$$
\text { (meta-analysis) }
$$

\section{Included studies}

Eleven studies were included in this review. All of them were single centre studies. All of the included studies were undertaken since the early 1990s by investigators attached to perinatal centres in North America, India, Thailand, Germany, Spain and Australia. A total of 574 neonates were enrolled in the 11 included trials. Krishnan 1997, Miron 2003 and Solomon 1999 enrolled infants of more than 32 weeks' gestation. Chotigeat 2001, Hagan 2002, Hayani 1997, Kosalaraksa 2004 and Thureen 1999 enrolled infants whose gestation was 34 weeks or more. Agarwal 2002 enrolled infants whose birth weight was $2500 \mathrm{~g}$ or more; and all except three of the neonates enrolled were above 37 weeks' gestation in this study. Skopnik 1992 enrolled only full-term neonates. de Alba Romero 1998 enrolled infants whose birth weight was $1200 \mathrm{~g}$ or more and was the only study to enrol preterm infants less than 32 weeks' gestational age.

All studies used intravenous infusion of gentamicin except Krishnan 1997, where gentamicin was given as a bolus over one minute. Hagan 2002 and Hayani 1997 used gentamicin both intravenously and intramuscularly. Of the 574 infants enrolled in the trial, only 39 infants had proven sepsis (Hayani 1997; de Alba Romero 1998; Hagan 2002; Miron 2003; Kosalaraksa 2004). The rest were treated for suspected sepsis. All studies used gentamicin in the dose of 4 to $5 \mathrm{mg} / \mathrm{kg} /$ day either as a single dose or as multiple divided doses. The main outcomes assessed were peak and trough levels of gentamicin and renal function. Three studies assessed hearing prior to discharge (Thureen 1999; Agarwal 2002; Hagan 2002); and one study assessed hearing at one to two months of age (Miron 2003). One study assessed the cost of therapy (Thureen 1999). The details are described in the table 'Characteristics of included studies'.

\section{Excluded studies}

Skopnik 1995, Davies 1998, Kaspers 1998, Lundergan 1999, Stickland 2001, Alsaedi 2003, Hansen 2003, Lanao 2004, Tantiprabha 2007, Thingvoll 2008, Gonzalez Santacruz M 2008, Serane 2009 and Hagen 2009 were excluded because they were not randomised or quasi-randomised controlled trials. English 2004 was excluded because a loading dose of $8 \mathrm{mg} / \mathrm{kg}$ was used in the 'once a day' gentamicin regimen, whereas no loading dose was used in the 'multiple doses a day' regimen. Mercado 2004 and Rastogi 2002 were excluded because they compared a 'once a day' to a 'once in 48 hours' regimen of gentamicin. Isemann 1996 and Semchuk 1995 were excluded because the regimen of loading dose was compared to the regimen of no loading dose of gentamicin. Tiwari 2009 was excluded because relevant data from the neonatal subgroup could not be obtained from the published article. We made three attempts to contact the authors but there was no response.

Yeung 2000, Hiltron 2010, Hossain 2009, Martinkova 2010, Alshaikh 2012, Fjalstad 2014, Hoff 2009, Krishnamoorthy 2013 and Low 2015 were also excluded because they were observational studies comparing 'once a day' dosing to different extended dosing regimens.

The details are listed in the table 'Characteristics of excluded studies'.

\section{Risk of bias in included studies}

The details of risk of bias are described in Figure 2. 
Figure 2. Risk of bias summary: review authors' judgements about each risk of bias item for each included study.

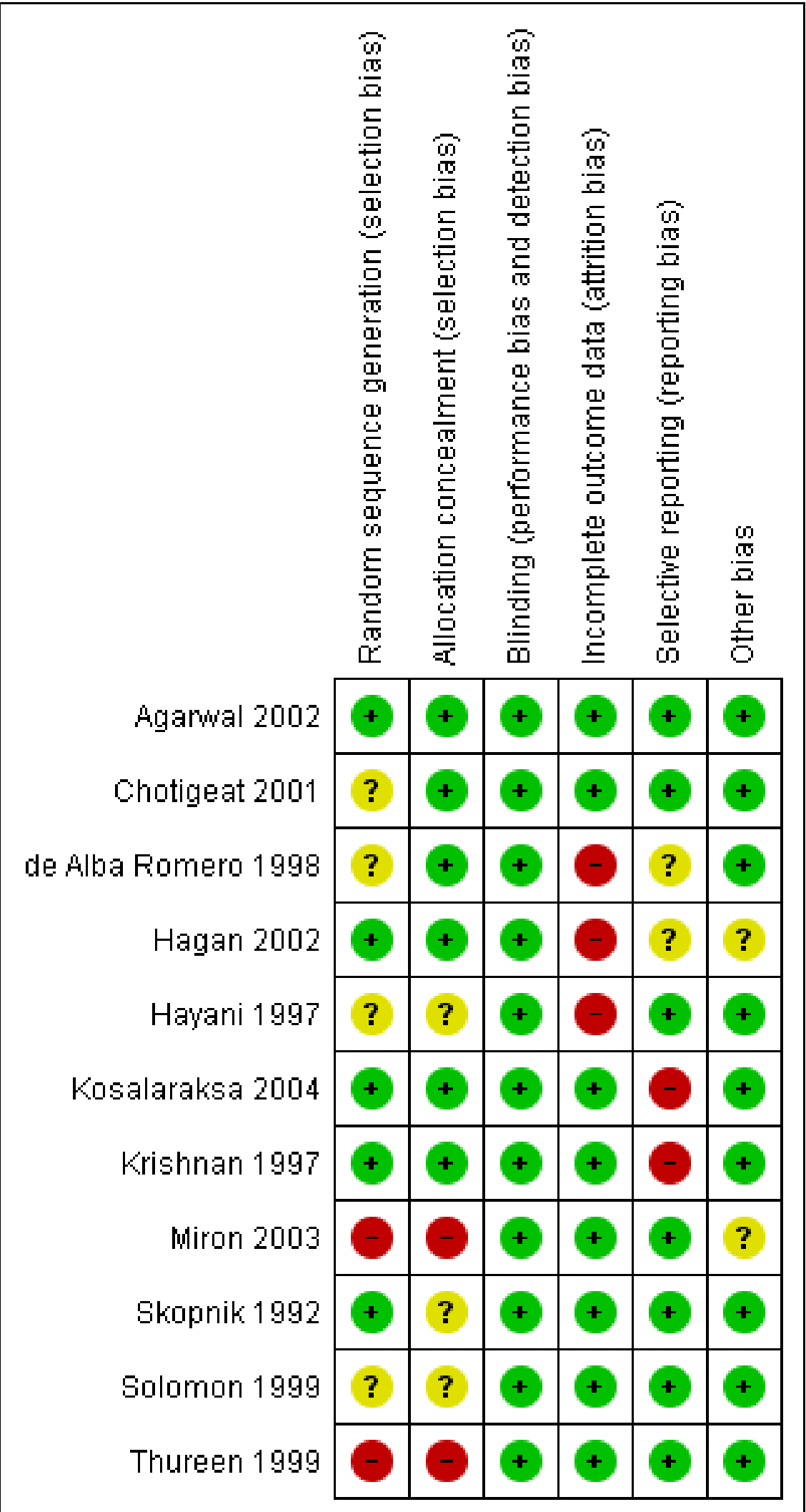

Details of the methodological quality of studies are included under the table 'Characteristics of included studies'. 


\section{Allocation}

Adequacy of sequence generation was accomplished using computer-generated random numbers in Skopnik 1992, Krishnan 1997, Agarwal 2002, Hagan 2002 and Kosalaraksa 2004.

\section{Allocation concealment:}

Allocation concealment was accomplished in Krishnan 1997, de Alba Romero 1998, Chotigeat 2001, Agarwal 2002, Hagan 2002 and Kosalaraksa 2004 using sealed envelopes. It was not clear if allocation was concealed in Solomon 1999, Skopnik 1992 and Hayani 1997. Allocation was not concealed in Miron 2003 and Thureen 1999. Miron 2003 was a quasi-random study with 'once a day' gentamicin being administered in period one (January to March 1998) and 'multiple doses a day' gentamicin being administered in period two (April to June 1998). Thureen 1999 was also a quasi-random study (assignment to a particular study group was dependent on the intensive care site, with monthly rotation of dosing regimens).

\section{Blinding}

\section{Blinding of intervention:}

Blinding of intervention was not done in any of the studies.

\section{Blinding of outcome assessment:}

Outcome assessment was blinded in Krishnan 1997, de Alba Romero 1998, Chotigeat 2001, Hagan 2002, Miron 2003 and Kosalaraksa 2004. It was not clear whether outcome assessment was blinded in Hayani 1997, Solomon 1999 and Agarwal 2002. It was not blinded in Skopnik 1992 and Thureen 1999.

\section{Incomplete outcome data}

Skopnik 1992, Krishnan 1997, Solomon 1999, Thureen 1999, Chotigeat 2001, Agarwal 2002, Miron 2003 and Kosalaraksa 2004 reported complete follow-up. Follow-up was incomplete in the Hayani 1997, Hagan 2002 and de Alba Romero 1998 trials, in that more than $10 \%$ of enrolled infants did not have outcomes assessed.

\section{Selective reporting}

Agarwal 2002, Chotigeat 2001, Hagan 2002, Hayani 1997, Miron 2003, Skopnik 1992, Solomon 1999 and Thureen 1999 reported predetermined outcome measures completely. In Kosalaraksa 2004, the statistical method to compare serum creatinine on day 0,3 and 7 was not pre-specified. They have not defined measures to evaluate clinical response within 72 hours of treatment. In Krishnan 1997, there was no pre-specified analysis method to measure nephrotoxicity but it was reported that there was no nephrotoxicity in either group at the end of therapy. In de Alba Romero 1998, outcome measures to determine clinical efficacy were not described.

\section{Other potential sources of bias}

All studies appeared to be free of other bias.

\section{Effects of interventions}

See: Summary of findings for the main comparison

Eleven studies fulfilled our selection criteria and were included in this review (Skopnik 1992; Krishnan 1997; Hayani 1997; de Alba Romero 1998; Solomon 1999; Thureen 1999; Chotigeat 2001; Agarwal 2002; Hagan 2002; Miron 2003; Kosalaraksa 2004). These studies included a total of 574 infants. There was no disagreement regarding inclusion/exclusion of studies, quality assessment or data extraction. Available data were pooled and analysed as listed below.

\section{Primary outcome measures}

\section{Clinical efficacy:}

All studies comparing 'once a day' versus 'multiple doses a day' regimen (Comparison 1)

\section{Clearance of proven sepsis (Outcome 1.1)}

Clearance of proven sepsis was defined as negative blood or other body fluid cultures without the need for changing antibiotic (Figure 3). In the de Alba Romero 1998 study, both 'once a day' and 'multiple doses a day' regimens achieved clearance of sepsis in all the 29 neonates with proven sepsis. There were two Gram-positive bacterial infections in the Kosalaraksa 2004 trial: we excluded them from analysis. Only one infant had proven sepsis in the study by Hayani 1997; its outcome was not reported. Hagan 2002 reported that all five infants with proven bacteriological sepsis in the 'once a day' gentamicin group responded by clearance of sepsis; and there were no cases of proven sepsis in the 'multiple doses a day' gentamicin group. Miron 2003 had one infant in each group with proven sepsis; both infants had clearance of sepsis after institution of antibiotic therapy. Meta-analysis of all studies did not show significant difference between the two groups (typical RR 1.00, 95\% $\mathrm{Cl} 0.84$ to 1.19 ; typical RD $0.00,95 \% \mathrm{Cl}-0.19$ to $0.19 ; 3$ trials; $\mathrm{N}=37$ ).

Figure 3. Forest plot of comparison: 1 All studies comparing 'once a day' versus 'multiple doses a day' regimen, outcome: 1.1 Clearance of proven sepsis.

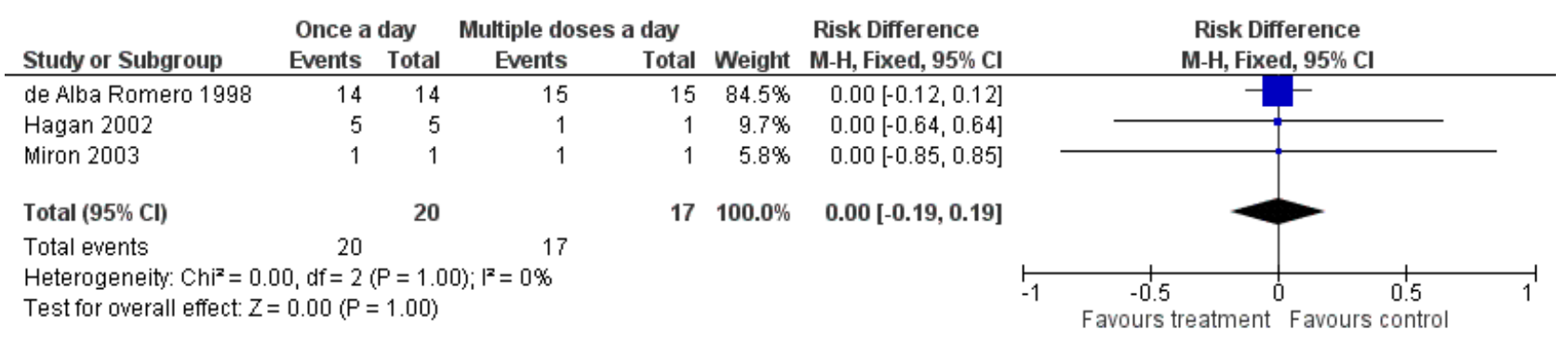




\section{Pharmacokinetic efficacy:}

Failure to attain peak levels of at least $5 \mu \mathrm{g} / \mathrm{ml}$ (Outcome 1.2)

Peak levels of at least $5 \mu \mathrm{g} / \mathrm{ml}$ were considered to be essential to declare that a particular dosing regimen was pharmacologically effective (Figure 4). Skopnik 1992, Hayani 1997, de Alba Romero 1998, Thureen 1999, Chotigeat 2001, Agarwal 2002, Hagan 2002, Miron 2003 and Kosalaraksa 2004 reported this outcome. Only
Miron 2003 reported a statistically significant difference that favoured 'once a day' gentamicin compared to 'multiple doses a day' gentamicin. However, meta-analysis of all the studies showed a statistically significant difference indicating that a 'once a day' regimen is associated with less failures than a 'multiple doses a day' regimen (typical RR $0.22,95 \% \mathrm{Cl} 0.11$ to 0.47 ; typical RD -0.13 , $95 \% \mathrm{Cl}-0.19$ to -0.08 ; number needed to treat for an additional beneficial outcome (NNTB) $=8 ; 9$ trials; $N=422$ ).

Figure 4. Forest plot of comparison: 1 All studies comparing 'once a day' versus 'multiple doses a day' regimen, outcome: 1.2 Failure to achieve peak levels of at least 5 microgram $/ \mathrm{ml}$.

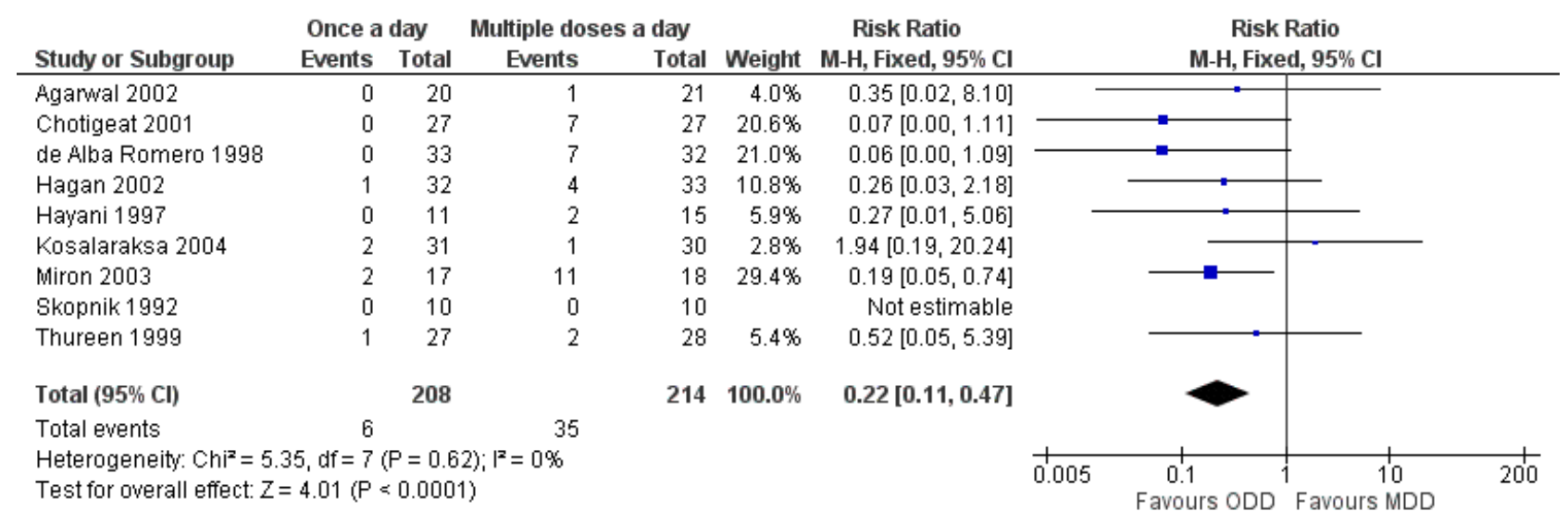

\section{Failure to achieve trough levels of $\leq 2 \mu \mathrm{g} / \mathrm{ml}$ (Outcome 1.3)}

Trough levels of $2 \mu \mathrm{g} / \mathrm{ml}$ or less were considered to be essential to declare that a particular dosing regimen was pharmacologically safe (Figure 5). All studies reported this outcome measure. Krishnan 1997, Thureen 1999, Miron 2003 and Kosalaraksa 2004 reported a statistically significant difference favouring 'once a day' gentamicin compared to 'multiple doses a day' gentamicin. Meta-analysis of all studies showed a statistically significant difference indicating that 'once a day' gentamicin groups are associated with fewer failures than 'multiple doses a day' regimens (typical RR $0.38,95 \% \mathrm{Cl} 0.27$ to 0.55 ; typical RD $-0.22,95 \% \mathrm{Cl}-0.29$ to -0.15 ; NNTB $=4 ; 11$ trials; $\mathrm{N}=503)$.

Figure 5. Forest plot of comparison: 1 All studies comparing 'once a day' versus 'multiple doses a day' regimen, outcome: 1.3 Failure to achieve trough levels of $\leq 2 \mathrm{microgram} / \mathrm{ml}$.

\begin{tabular}{|c|c|c|c|c|c|c|c|c|c|c|}
\hline \multirow[b]{2}{*}{ Study or Subgroup } & \multicolumn{2}{|c|}{ Once a day } & \multicolumn{2}{|c|}{ Multiple doses a day } & \multicolumn{3}{|c|}{ Risk Ratio } & \multirow{2}{*}{\multicolumn{2}{|c|}{$\begin{array}{c}\text { Risk Ratio } \\
\text { M-H, Fixed, } 95 \% \mathrm{Cl} \\
\end{array}$}} & \\
\hline & Events & Total & Events & Total & Weight & M-H, Fixed, 95\% Cl & & & & \\
\hline Agawwal 2002 & 0 & 20 & 4 & 21 & $4.9 \%$ & $0.12[0.01,2.03]$ & $\longleftarrow$ & & & \\
\hline Chotigeat 2001 & 0 & 27 & 2 & 27 & $2.8 \%$ & $0.20[0.01,3.98]$ & & & & \\
\hline de Alba Romero 1998 & 8 & 33 & 13 & 32 & $14.8 \%$ & $0.60[0.29,1.24]$ & & & - & \\
\hline Hagan 2002 & 7 & 32 & 4 & 33 & $4.4 \%$ & $1.80[0.58,5.58]$ & & & & \\
\hline Hayani 1997 & 1 & 11 & 6 & 15 & $5.7 \%$ & $0.23[0.03,1.63]$ & & & & \\
\hline Kosalaraksa 2004 & 6 & 21 & 20 & 30 & $18.5 \%$ & $0.43[0.21,0.88]$ & & & & \\
\hline Krishnan 1997 & 0 & 9 & 9 & 9 & $10.7 \%$ & $0.05[0.00,0.79]$ & $\leftarrow$ & & & \\
\hline Miron 2003 & 3 & 17 & 10 & 18 & $10.9 \%$ & $0.32[0.11,0.96]$ & & & & \\
\hline Skopnik 1992 & 0 & 10 & 0 & 10 & & Not estimable & & & & \\
\hline Solomon 1999 & 6 & 37 & 10 & 36 & $11.4 \%$ & $0.58[0.24,1.44]$ & & & 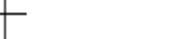 & \\
\hline Thureen 1999 & 0 & 27 & 14 & 28 & $16.0 \%$ & $0.04[0.00,0.57]$ & & & & \\
\hline Total $(95 \% \mathrm{Cl})$ & & 244 & & 259 & $100.0 \%$ & $0.38[0.27,0.55]$ & & & & \\
\hline Total events & 31 & & 92 & & & & & & & \\
\hline $\begin{array}{l}\text { Heterogeneity: } \mathrm{Ch}^{2}=1 \\
\text { Test for overall effect: } Z\end{array}$ & $\begin{array}{l}67, \mathrm{df}=\mathrm{g} \\
5.32(\mathrm{P}\end{array}$ & $\begin{array}{l}(P=0 . \\
0.0000\end{array}$ & $\begin{array}{l}07) ;\left.\right|^{2}=43 \% \\
01)\end{array}$ & & & & 0.01 & $\begin{array}{l}0.1 \\
\text { Favours ODD }\end{array}$ & $1 \frac{10}{\text { Favours MDD }}$ & 100 \\
\hline
\end{tabular}




\section{Secondary outcome measures}

\section{Ototoxicity (Outcome 1.4)}

- Auditory: defined as changes in pure tone audiometry or brainstem evoked auditory responses or otoacoustic emissions or any other validated hearing tests.

- Vestibular: defined as changes in electronystagmography or any other validated vestibular function test.

Four studies assessed auditory toxicity (Analysis 1.4) (de Alba Romero 1998; Thureen 1999; Agarwal 2002; Hagan 2002). Thureen 1999 replied that all infants in both the 'once a day' and 'multiple doses a day' gentamicin groups passed hearing screening tests. Hagan 2002 used otoacoustic emission tests both prior to the first dose and after the third dose of gentamicin and did not find evidence of ototoxicity in either group. Agarwal 2002 performed hearing screening tests prior to discharge; none of their study infants failed hearing tests. de Alba Romero 1998 reported two cases of ototoxicity out of 13 in the 'once a day' group compared to one out of 11 in the 'multiple doses a day' regimen. Chotigeat 2001 performed the tests for ototoxicity but did not report the results. Meta-analysis of all the studies showed no statistically significant differences in ototoxicity between the two groups (typical RR 1.69 , $95 \% \mathrm{Cl} 0.18$ to 16.25 ; typical RD $0.01,95 \% \mathrm{Cl}-0.04$ to 0.05 ; 5 trials; $\mathrm{N}=214)$.

Vestibular toxicity was not tested by any of the studies.

\section{Nephrotoxicity (Outcome 1.5)}

- Primary: any increase in serum creatinine levels or decrease in creatinine clearance, with thresholds as defined in each study.

- Secondary: urinary excretion of proteins (retinal binding protein, beta-2 microglobulin, Clara cell protein, microalbumin, N-Acetyl-Beta-D-glucosaminidase, alkaline phosphatase, alanine aminopeptidase, or gamma-glutamyl transferase) or phospholipids.

Skopnik 1992, Hayani 1997, Krishnan 1997, de Alba Romero 1998, Chotigeat 2001, Agarwal 2002, Hagan 2002, Miron 2003 and
Kosalaraksa 2004 reported this outcome (Figure 6). Agarwal 2002 monitored renal functions by measuring 24-hour urine output on days one, two and three of therapy. Serum electrolytes, blood urea nitrogen and serum creatinine were measured on days two and three of the study. Creatinine clearance and FENa were measured on days two and three of therapy. There were no significant differences between the two groups in all the outcomes measured. Chotigeat 2001 measured serum creatinine before the beginning of treatment and on the third day and the last day of therapy; there was no significant difference between the two dosage regimens. Hagan 2002 measured serum creatinine levels before the beginning of study and subsequently on a daily basis till the completion of treatment; there was no significant difference between the two dosage regimens. Hayani 1997 measured serum creatinine and GFR before therapy and on day two or three of therapy. They also measured urinary beta-2 microglobulin levels before and after completion of therapy. There was no significant difference between the two regimens. Kosalaraksa 2004 measured serum creatinine on day zero, three and seven or the last day of therapy; there was no nephrotoxicity in either group. Krishnan 1997 measured serum creatinine before and at the end of therapy and found no significant difference in creatinine levels between the two groups. There was no nephrotoxicity in either group. Miron 2003 measured serum and urine creatinine and sodium concentrations, urinary lysozyme excretion, glomerular filtration rate and fractional excretion of sodium at 72 to 96 hours of therapy. The values were not significantly different between the two groups; and none of the babies in either group developed nephrotoxicity. de Alba Romero 1998 measured the N-Acetyl-Beta-D-glucosaminidase:creatinine ratio as a sensitive indicator of gentamicin-induced nephrotoxicity. First-morning urine within the first two days and on the seventh day of treatment was analyzed. The enzyme levels increased in urine in both groups, more so in the 'multiple doses a day' gentamicin group; however, there was no significant difference. Skopnik 1992 measured urinary aminopeptidase levels as a marker of nephrotoxicity and found that it was increased in both groups in the same pattern during and after discontinuation of gentamicin therapy.

\section{Figure 6. Forest plot of comparison: 1 All studies comparing 'once a day' versus 'multiple doses a day' regimen,} outcome: 1.5 Nephrotoxicity.

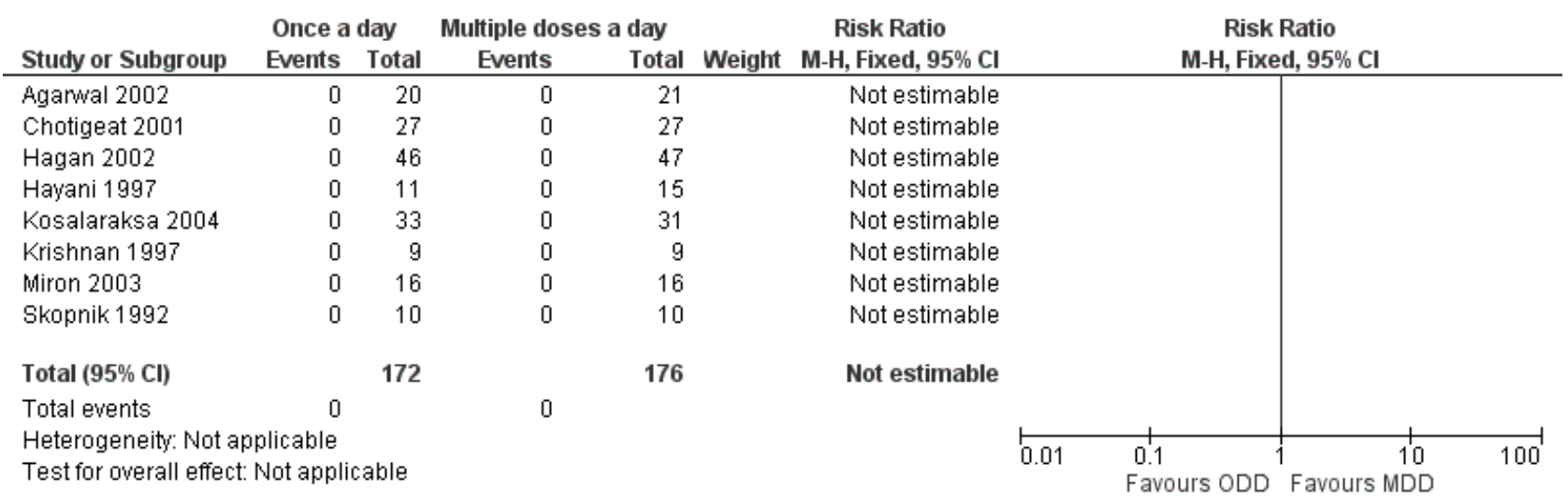

\section{Treatment failure (Outcome 1.6)}

Treatment failure was defined as persistent positive blood/body fluid or tissue cultures which led to addition of new antibiotic
(Analysis 1.6). de Alba Romero 1998, Hagan 2002 and Miron 2003 reported in total 36 infants with proven sepsis. There were no treatment failures in either the 'once a day' or the 'multiple doses a

One dose per day compared to multiple doses per day of gentamicin for treatment of suspected or proven sepsis in neonates (Review) 
day' regimens (typical RR $0.0,95 \% \mathrm{Cl} 0.0$ to 0.0 ; typical RD $0.00,95 \%$ $\mathrm{Cl}-0.19$ to $0.19 ; 3$ trials; $\mathrm{N}=36$ ).

\section{Actual peak levels (mean and SD) attained $(\mu \mathrm{g} / \mathrm{ml})$ ) (Outcome 1.7)}

Peak levels were defined as levels measured at 0.5 to 1 hour after a dose of gentamicin (Analysis 1.7). All studies except Solomon 1999 reported this outcome. All studies except Krishnan 1997 reported a statistically significant difference with higher peak levels attained in the 'once a day' gentamicin regimen. Meta-analysis of the 10 studies involving a total of 440 infants showed a statistically significant difference between the 'once a day' and the 'multiple doses a day' gentamicin regimens with higher peak levels attained in the 'once a day' regimens (MD 2.58, 95\% $\mathrm{Cl} 2.26$ to $2.89 ; 10$ trials; $\mathrm{N}=440$ ). Analysis showed significant heterogeneity and hence should be interpreted with caution.

\section{Actual trough levels (mean and SD) attained $(\mu \mathrm{g} / \mathrm{ml}$ ) (Outcome 1.8)}

Trough levels are defined as levels measured prior to within one hour of giving any dose of gentamicin (except the initial dose) (Analysis 1.8). All studies except Solomon 1999 reported this outcome. All studies except Hagan 2002 and Hayani 1997 showed statistically significant lower trough levels in the 'once a day' compared to the 'multiple doses a day' gentamicin regimens. Metaanalysis of all the studies showed statistically significant lower trough levels in the 'once a day' regimen versus the 'multiple doses a day' gentamicin regimen (MD $-0.57,95 \% \mathrm{Cl}-0.69$ to -0.44 ; 10 trials; $\mathrm{N}=440$ ). Analysis showed significant heterogeneity and hence should be interpreted with caution.

\section{Subgroup analysis of intramuscular gentamicin}

Hayani 1997 and Hagan 2002 used gentamicin intramuscularly in some of their study infants. Separate data for the intramuscular gentamicin was not available from Hagan 2002. Hayani 1997 reported the outcomes on four infants with 'once a day' gentamicin, but combined the data for intramuscular and intravenous gentamicin in the 'multiple doses a day' regimen because there was no significant difference in the pharmacokinetic parameters between these groups. The peak gentamicin levels in the 'once a day ' group were significantly higher $(P<0.05)$ than the 'multiple doses a day' group $(11.2 \pm 2.0 \mu \mathrm{g} / \mathrm{ml}$ versus $6.6 \pm 1.3 \mu \mathrm{g} / \mathrm{ml})$. The trough levels were significantly lower $(P<0.05)$ in the 'once a day' group compared to the 'multiple doses a day' group $(1.1 \pm 0.3 \mu \mathrm{g} /$ $\mathrm{ml}$ versus $1.7 \pm 0.5 \mu \mathrm{g} / \mathrm{ml}$ ).

\section{Subgroup analysis of infants with proven sepsis}

As previously noted, very few infants had proven sepsis in the included studies. In the de Alba Romero 1998 study, 14 infants (42\%) in the 'once a day' group and 15 infants (47\%) in the 'multiple doses a day' group had bacteriological sepsis. All infants had clearance of sepsis in both groups. Only one infant had proven sepsis in the study by Hayani 1997; the outcome of this infant was not reported. Two infants had proven Gram-positive sepsis in the study by Kosalaraksa 2004, one in each group of the 'once a day' and the 'multiple doses a day' regimen; however, they were excluded from analysis. Hagan 2002's study reported that all five infants with proven bacteriological sepsis in the 'once a day' gentamicin group responded by clearance of sepsis. There were no cases of proven sepsis in the 'multiple doses a day' gentamicin group. Miron 2003 had one infant in each group with proven sepsis; both infants had clearance of sepsis after institution of antibiotic therapy. Meta-analysis of all the studies did not show significant difference between the two groups (typical RD $0.00,95 \% \mathrm{Cl}-0.19$ to 0.19$) ; 3$ trials, $N=36$ ). Other outcomes were not reported for this subgroup of infants.

\section{Subgroup analysis of infants less than 32 weeks' gestation}

de Alba Romero 1998 had seven infants with gestational age less than 32 weeks; all were treated for suspected sepsis. All infants in both groups achieved peak levels of more than $5 \mu \mathrm{g} / \mathrm{ml}$. Three out of five infants in the 'once a day' group had toxic trough levels of more than $2 \mu \mathrm{g} / \mathrm{ml}$. Both infants in the 'multiple doses a day' regimen had toxic trough levels of more than $2 \mu \mathrm{g} / \mathrm{ml}$. No other study enrolled infants of less than 32 weeks' gestation.

\section{Subgroup analysis of infants in whom loading dose was used in both 'once a day' and 'multiple doses a day' regimen}

None of the studies used a loading dose of gentamicin in both the study and control regimens.

Sensitivity analysis by excluding studies where trial participants were of extremely low gestational age could not be done because no studies included such infants.

\section{DISCUSSION}

\section{Summary of main results}

The outcome of 574 neonates from 11 RCTs comparing 'once a day' versus 'multiple doses a day' gentamicin have been reported in this review. For the primary outcome of 'Clearance of proven sepsis', there was no statistically significant difference between the 'once a day' and 'multiple doses a day' regimens of gentamicin. Both treatment regimes were successful at treating infants with proven sepsis. However, the numbers were too small to arrive at definite conclusions. This is as expected because only a very small percentage of neonates with suspected sepsis have a culturepositive infection (Stoll 1996a; Stoll 1996b). For the primary outcomes of 'Failure to attain peak levels of at least $5 \mu \mathrm{g} / \mathrm{ml}$ ', and 'Failure to achieve trough levels of $<2 \mu \mathrm{g} / \mathrm{ml}$ ', meta-analysis showed a statistically significant difference favouring the 'once a day' gentamicin group. 'Once a day' gentamicin was associated with lower pharmacokinetic failure rates than the 'multiple doses a day' regimen.

For the secondary outcomes of 'Actual peak levels' and 'Actual trough levels' attained, meta-analysis showed that a 'once a day' regimen achieved higher peak levels and lower trough levels compared to a 'multiple doses a day' regimen. However significant heterogeneity was noticed for these two outcomes and therefore these results need to be interpreted with caution. Heterogeneity was explored by re-checking entered data and by excluding individual studies one at a time. Individual trials were studied in detail to explore the cause of heterogeneity. Krishnan 1997, Solomon 1999 and Miron 2003 enrolled infants of more than 32 weeks' gestation. Hayani 1997, Thureen 1999, Chotigeat 2001, Hagan 2002 and Kosalaraksa 2004 enrolled infants of more than 34 weeks' gestation. Agarwal 2002 enrolled infants whose birth weight was $2500 \mathrm{~g}$ or above regardless of gestation age. Skopnik 1992 enrolled only full-term neonates. de Alba Romero 1998 enrolled infants with birth weight of $1200 \mathrm{~g}$ or above. These differences 
in gestational age and birth weight might have contributed to heterogeneity. All studies used a similar dose of gentamicin (4 to $5 \mathrm{mg} / \mathrm{kg} /$ day). Timing of collection of the blood samples for trough levels was the same in all the studies (within 30 minutes of administration of the next dose). Samples for peak levels were collected between 30 to 60 minutes after administration of the dose. The day of therapy on which samples were collected varied between day one to day five; this variation in the day and time of collection of the samples may also have led to heterogeneity. Hagan 2002 and Hayani 1997 used gentamicin both intramuscularly and intravenously; however, significant heterogeneity still remained even when these two studies were excluded from the metaanalysis. Results remained the same when data were re-analysed using a random-effects model instead of a fixed-effect model.

de Alba Romero 1998 reported less nephrotoxicity in the 'once a day' gentamicin regimen compared to the 'multiple doses a day' regimen. They measured urinary levels of N-Acetyl-Beta-Dglucosaminidase as the marker of nephrotoxicity. All other seven studies found no difference in the risk of nephrotoxicity between 'once a day' and 'multiple doses a day' gentamicin regimens. In a prospective study, Nielsen 2009 evaluated the use of cystatin C along with serum creatinine as a marker of gentamicin clearance and concluded that neither of them correlated with gentamicin clearance. They also concluded that serum creatinine and cystatin $C$ were not predictive markers of renal function in their population set (Nielsen 2009). Coscia 2008 evaluated the nephrotoxic effects of 'once a day' netilmicin with multiple doses a day in preterm neonates (GA $<37$ weeks). The 'once a day' regimen had the same low rates of nephrotoxicity as multiple doses a day, suggesting the possible advantages of the 'once a day' regimen. An RCT in adults measured urinary alanine aminopeptidase (AAP) and $\mathrm{N}$ Acetyl-Beta-D-glucosaminidase (NAG) as markers of nephrotoxicity and found that 'once a day' tobramycin was less nephrotoxic than a 'multiple doses a day' regimen (Olsen 2004). Accurately evaluating nephrotoxicity within a neonatal population remains challenging as renal function undergoes rapid maturation in the early weeks after birth and preterm neonates have an initial rise in creatinine (Blackburn 1994; Kent 2014). The GFR increases rapidly at birth and doubles during the first few weeks after birth (Blackburn 1994). Therefore, using creatinine or GFR to determine aminoglycoside-induced nephrotoxicity may be suboptimal in neonates. As proximal tubule toxicity is the primary mechanism of aminoglycoside nephrotoxicity, urinary biomarkers have been used to measure nephrotoxicity. However, the clinical significance of raised urinary levels associated with normal plasma creatinine levels and normal urine output is unknown (Kent 2014). McWilliams 2012 studied urinary kidney injury molecule 1 (KIM-1) and other biomarkers in neonates receiving gentamicin therapy. Although univariate analysis indicated significant association between aminoglycoside toxicity and urinary KIM-1, urinary N-Acetyl-BetaD-glycosaminidase, and urinary neutrophil gelatinase-associated lipocalin, in multivariate analysis only urinary KIM-1 elevation was significantly correlated with aminoglycoside treatment, whereas other urinary biomarkers fell out of significance.

Only five studies assessed, and four studies reported, auditory toxicity. No difference was noted between the two groups. Vestibular toxicity was not assessed in any of the studies possibly due to difficulties assessing vestibular function in neonates. Our results are similar to the findings of the systematic review by Kent 2014, (gentamicin $(n)=577$ ) that found no clear association between peak or trough levels and ototoxicity in neonates. In that review, 22 children (3.8\%) were identified as having gentamicin ototoxicity but the authors hypothesized the possibility of a potential overestimation as no repeat tests were performed for verifications following an initial failed hearing screen. Setiabudy 2013 assessed hearing function in neonates with sepsis receiving 24 to 48 hourly aminoglycides using an otoacoustic emission instrument and found no relationship between trough levels and ototoxocity. Similary, El-Barbary 2015 compared NICU neonates receiving 'once a day' gentamicin to no gentamicin and found that the incidence of hearing loss is comparable in each arm; and longer duration ( $>5$ days) had no impact on their findings. While these findings are reassuring, it is important to exercise caution and use gentamicin only for the minimum duration possible in neonates. In children, the chances of gentamicin ototoxicity is reported to be greater in those who receive the drug for a longer duration (Kent 2014). The limitations of the included studies in our review were lack of long-term follow-up testing and failure to take into account other potential risk factors such as concomitant use of ototoxic agents.

A 'once a day' gentamicin regimen requires less pharmacy preparation time and less nursing administration time. Thureen 1999 evaluated the cost-effectiveness analysis of 'once a day' gentamicin among neonates and found that a 'once a day' gentamicin regimen was more cost effective than a 'multiple doses a day' regimen. Individualized dosing regimens may be ideal, but are more expensive as they require more frequent measurement of gentamicin levels. Measurement of gentamicin levels is the major contributor to the expense of administering this relatively inexpensive drug (Thureen 1999; Bajaj 2004). As the great majority of infants treated with gentamicin are treated only for a short time (48 to 72 hours) until deep infection is excluded, this would increase the cost and complexity of their care with no clinical benefit. Therefore, the use of a reliable dosage regimen which then ensures maximum pharmacokinetic efficacy would be beneficial. Although our review was unable to demonstrate superior clinical efficacy of 'once a day' gentamicin, the superiority of 'once a day' gentamicin in achieving less pharmacokinetic failures suggested therapeutic drug monitoring may not be required if gentamicin is used for a short time.

Five out of seven infants of less than 32 weeks' gestation developed toxic trough levels of more than $2 \mu \mathrm{g} / \mathrm{ml}$. This occurred in both 'once a day' and 'multiple doses a day' regimens indicating that even a 'once a day' regimen may also be toxic in preterm neonates. The possible explanation is that very preterm infants have lower glomerular filtration rates and hence clear gentamicin more slowly than the more mature infants. In a recent retrospective study of 993 newborn infants, more than $20 \%$ in a group of preterm infants born between 28 and 31 weeks of gestation receiving 'once a day' gentamicin had an elevated trough level of more than $2 \mu \mathrm{g} / \mathrm{ml}$; while infants born at less than 28 weeks and more than 35 weeks of gestation who received 36-hourly and 24-hourly gentamicin respectively had very low rates of elevated trough levels. Furthermore, indomethacin co-administration resulted in a significantly higher median gentamicin level compared to infants of similar gestation who did not receive indomethacin (König 2015). There are several studies evaluating factors influencing gentamicin pharmacokinetics in neonates. Fuchs 2014, an observational study including 3039 neonates, found that body weight and age are the most important factors affecting gentamicin dosage. Another 
recent population pharmacokinetics study described gentamicin pharmacokinetics in the newborn and, finding creatinine clearance a more important predictor of elimination of gentamicin in preterm infants, proposed 48-hourly dosing for those neonates less than 32 weeks of gestational age (García 2006). Evidence is accumulating that an extended dosing regimen of once in 36 to 48 hours may be more suitable for very preterm infants (less than 32 weeks' gestation) (Rastogi 2002; Hansen 2003; Mercado 2004; Thingvoll 2008; García 2006; König 2015; Lulic-Botica 2013; Valitalo 2015; Fullas 2011).

\section{Overall completeness and applicability of evidence}

There is some evidence to support the use of 'once a day' dosing of gentamicin in neonates.

\section{Quality of the evidence}

Overall, the quality of evidence was considered to be moderate on GRADE analysis, given the small sample size and unclear/high risk of bias in some of the domains in a few of the included studies.

\section{Potential biases in the review process}

None to our knowledge.

\section{Agreements and disagreements with other studies or reviews}

The findings of this review are similar to the meta-analysis in neonates, older children and adults in that 'once a day' gentamicin appears to be comparable in its clinical efficacy, nephrotoxicity and ototoxicity to that of 'multiple doses a day' (Barza 1996; Contopoulos-Ioannidis 2004; Bailey 1997; Ali 1997; Munckhof 1996; Nestaas 2005).

\section{AUTHORS' CONCLUSIONS}

\section{Implications for practice}

There is insufficient evidence from the currently available RCTs to conclude whether a 'once a day' or a 'multiple doses a day' regimen of gentamicin is superior in treating bacteriologically confirmed neonatal sepsis. However, the pharmacokinetic properties of a 'once a day' gentamicin regimen are superior to 'multiple doses a day' gentamicin in that it achieves higher peak levels while avoiding toxic trough levels. There appear to be no differences in nephrotoxicity or auditory toxicity. Hence a 'once a day' regimen may be superior in treating neonatal sepsis in neonates of more than 32 weeks' gestation.

\section{Implications for research}

Studies comparing the 'multiple doses per day' and 'one dose per day' regimens for microbiologically confirmed sepsis requiring prolonged antibiotic therapy need to be done to confirm if the pharmacokinetic benefits translate into clinical efficacy and safety. It is also important to follow such neonates long term to find out the effects on hearing and speech.

\section{ACKNOWLEDGEMENTS}

We are thankful to the authors of Krishnan 1997, de Alba Romero 1998, Thureen 1999, Chotigeat 2001, Hagan 2002, Miron 2003, Kosalaraksa 2004 and Skopnik 1992 for responding to our queries. We are thankful to the lead author of Gonzalez Santacruz M 2008 for providing the translated version of their Spanish article. We are also very thankful to Kathleen Martin, reference librarian at the Canberra Hospital library, Australia for her help in performing the literature search for the initial review (2008). We are very much thankful to Jane Bell, Research Officer, Australasian Coordinating Network for the Cochrane Neonatal Review Group for her valuable help in the literature search for the initial review and suggestions in editing the protocol.

The Cochrane Neonatal Review Group has been funded in part with Federal funds from the Eunice Kennedy Shriver National Institute of Child Health and Human Development National Institutes of Health, Department of Health and Human Services, USA, under Contract No. HHSN267200603418C. 


\section{R E F E R E N C E S}

\section{References to studies included in this review}

Agarwal 2002 \{published data only\}

Agarwal G, Rastogi A, Pyati S, Wilks A, Pildes RS. Comparison of once-daily versus twice-daily gentamicin dosing regimens in infants $>$ or $=2500$ g. Journal of Perinatology 2002;22(4):268-74.

\section{Chotigeat 2001 \{published data only\}}

Chotigeat U, Narongsanti A, Ayudhya DP. Gentamicin in neonatal infection: once versus twice daily dosage. Journal of Medical Association of Thailand 2001;84(8):1109-15.

\section{de Alba Romero 1998 \{published data only\}}

de Alba Romero C, Gomez Castillo E, Manzanares Secades C, Rodriguez Lopez J, Arreaza Lopez L, Saenz Valiente P. Once daily gentamicin dosing in neonates. Pediatric Infectious Disease Journal 1998;17(12):1169-71.

\section{Hagan 2002 \{unpublished data only\}}

Hagan R. Gentamicin in neonates: single vs multiple doses. Abstract book PSANZ 2002. 2002.

\section{Hayani 1997 \{published data only\}}

Hayani KC, Hatzopoulos FK, Frank AL, Thummala MR, Hantsch MJ, Schatz BM, et al. Pharmacokinetics of oncedaily dosing of gentamicin in neonates. Journal of Pediatrics 1997;131(1 Pt 1):76-80.

\section{Kosalaraksa 2004 \{published data only\}}

Kosalaraksa P, Janthep P, Jirapradittha J, Taksaphan S, Kiatchoosakun P. Once versus twice daily dose of gentamicin therapy in Thai neonates. Journal of the Medical Association of Thailand 2004;87(4):372-6.

\section{Krishnan 1997 \{published data only\}}

Krishnan L, George SA. Gentamicin therapy in preterms: a comparison of two dosage regimens. Indian Pediatrics 1997;34(12):1075-80.

\section{Miron 2003 \{published data only\}}

Miron D, Steinfeld M, Hasanein J, Felszer C, Reich D. Tolerability of once-daily-dosing of intravenous gentamicin in preterm neonates born at 32-37 weeks of gestation. Harefuah 2003;142(6):413-5.

\section{Skopnik 1992 \{published data only\}}

Skopnik H, Wallraf R, Nies B, Troster K, Heimann G. Pharmacokinetics and antibacterial activity of daily gentamicin. Archives of Diseases in Childhood 1992;67(1 Spec No):57-61.

\section{Solomon 1999 \{published data only\}}

Solomon R, Kuruvilla KA, Job V, Selvakumar R, Jeyaseelan L, Kanagasabapathy AS, et al. Randomized controlled trial of once vs. twice daily gentamicin therapy in newborn. Indian Pediatrics 1999;36(2):133-7.

\section{Thureen 1999 \{published data only\}}

Thureen PJ, Reiter PD, Gresores A, Stolpman NM, Kawato K, Hall DM. Once- versus twice-daily gentamicin dosing in neonates >=34 weeks' gestation: cost-effectiveness analyses. Pediatrics 1999;103(3):594-8.

\section{References to studies excluded from this review}

Alsaedi 2003 \{published data only\}

Alsaedi SA. Once daily gentamicin dosing in full term neonates. Saudi Medical Journal 2003;24(9):978-81.

Alshaikh 2012 \{published data only\}

Alshaikh B, Dersch-Mills D, Taylor R, Akierman AR, Yusuf K. Extended interval dosing of gentamicin in premature neonates $\leq 2$-week gestation. Acta Paediatrica 2012;101(11):1134-9. [PUBMED: 22897142]

Davies 1998 \{published data only\}

Davies MW, Cartwright DW. Gentamicin dosage intervals in neonates: longer dosage interval--less toxicity. Journal of Paediatrics and Child Health 1998;34(6):577-80

English 2004 \{published data only\}

English M, Mohammed S, Ross A, Ndirangu S, Kokwaro G, Shann F, et al. A randomised, controlled trial of once daily and multi-dose daily gentamicin in young Kenyan infants. Archives Of Disease in Childhood 2004;89(7):665-9.

Fjalstad 2014 \{published data only\}

Fjalstad JW, Laukli E, van den Anker JN, Klingenberg C. Highdose gentamicin in newborn infant: is it safe?. European Journal of Paediatrics 2014;173(4):489-95. [PUBMED: 10717501]

Gonzalez Santacruz M 2008 \{published data only\}

Gonzalez Santacruz M, Tarazona Fargueta JL, Ferrandis Rodriguez O, Tapia Collados C, Jimenez Cobo B. Comparison of two gentamicin dosing schedules in the newborn. Anales de pediatría 2008;68(6):581-8.

Hagen 2009 \{published data only\} Hagen I, Oymer K. Pharmacological differences between once and twice daily gentamicin dosage in newborns with suspected sepsis. Pharmacy World and Science 2009;31(1):18-23.

Hansen 2003 \{published data only\}

Hansen A, Forbes P, Arnold A, O'Rourke E. Once-daily gentamicin dosing for the preterm and term newborn: proposal for a simple regimen that achieves target levels. Journal of Perinatology 2003;23(8):635-9.

Hiltron 2010 \{published data only\}

Hiltron AE, Sun Y, Scarpace SB. Accuracy of empiric gentamicin dosing guidelines in neonates. The Journal of Pediatric Pharmacology and Therapeutics 2010;15(4):264-73. [PUBMED: 22477814]

Hoff 2009 \{published data only\}

Hoff DS, Wilcox RA, Tollefson LM, Lipnik PG, Commers AR, Liu M. Pharmacokinetic outcomes of a simplified, weight-based, extended-interval gentamicin dosing protocol in critically ill 
neonates. Pharmacotherapy 2009;29(11):1297-305. [PUBMED: 19857147]

\section{Hossain 2009 \{published data only\}}

Hossain MM, Chowdhury NA, Shirin MS, Saha SK, Miller-Bell M, Edwards D, et al. Simplified dosing of gentamicin for treatment of sepsis in Bangladeshi neonates. Journal of Health, Population and Nutrition 2009;27(5):640-5. [PUBMED: 19902799]

\section{Isemann 1996 \{published data only\}}

Isemann BT, Kotagal UR, Mashni SM, Luckhaupt EJ, Johnson CJ. Optimal gentamicin therapy in preterm neonates includes loading doses and early monitoring. Therapeutic Drug Monitoring 1996;18(5):549-55.

\section{Kaspers 1998 \{published data only\}}

Kaspers GJ, Teunissen PC, Holl H. Gentamicin administration in newborns: once daily. Nederlands Tijdschrift voor Geneeskunde 1998;142(11):583-6.

\section{Krishnamoorthy 2013 \{published data only\}}

Krishnamoorthy SS, Nair A, Furness J, Sanderson J. Gentamicin use in neonates: should we have a change of practice?. Scottish Medical Journal 2013;58(4):241-5. [PUBMED: 24215045]

\section{Lanao 2004 \{published data only\}}

Lanao JM, Calvo MV, Mesa JA, Martin-Suarez A, Carbajosa MT, Miguelez $F$, et al. Pharmacokinetic basis for the use of extended interval dosage regimens of gentamicin in neonates. Journal of Antimicrobial Chemotherapy 2004;54(1):193-8.

\section{Low 2015 \{published data only\}}

Low YS, Tan SL, Wan AS. Extended-interval gentamicin dosing in achieving therapeutic concentrations in Malaysian neonates. Journal of Pediatric Pharmacology and Therapeutics 2015;20(2):119-25. [PUBMED: 25964729]

\section{Lundergan 1999 \{published data only\}}

Lundergan FS, Glasscock GF, Kim EH, Cohen RS. Once-daily gentamicin dosing in newborn infants. Pediatrics 1999;103(6 Pt 1):1228-34

\section{Martinkova 2010 \{published data only\}}

Martinkova J, Pokorna P, Zahora J, Chladek J, Vobruba V, SelkeKrulichova I, et al. Tolerability and outcomes of kinetically guided therapy with gentamicin in critically ill neonates during the first week of life: An open-label, prospective study. Clinical Therapeutics 2010;32(14):2400-14. [PUBMED: 21353108]

\section{Mercado 2004 \{published data only\}}

Mercado MC, Brodsky NL, McGuire MK, Hurt H. Extended interval dosing of gentamicin in preterm infants. American Journal of Perinatology 2004;21(2):73-7.

\section{Rastogi 2002 \{published data only\}}

Rastogi A, Agarwal G, Pyati S, Pildes RS. Comparison of two gentamicin dosing schedules in very low birth weight infants. Pediatric Infectious Disease Journal 2002;21(3):234-40.
Semchuk 1995 \{published data only\}

Semchuk W, Shevchuk YM, Sankaran K, Wallace SM. Prospective, randomized, controlled evaluation of a gentamicin loading dose in neonates. Biology of the Neonate 1995;67(1):13-20.

\section{Serane 2009 \{published data only\}}

Serane TV, Zengeya S, Penford G, Cooke J, Khanna G, McGregorColman E. Once daily dose gentamicin in neonates - is our dosing correct?. Acta Paediatrica 2009;98(7):1100-5.

\section{Skopnik 1995 \{published data only\}}

Skopnik H, Heimann G. Once daily aminoglycoside dosing in full term neonates. Pediatric Infectious Disease Journal 1995;14(1):71-2.

\section{Stickland 2001 \{published data only\}}

Stickland MD, Kirkpatrick CM, Begg EJ, Duffull SB, Oddie SJ, Darlow BA. An extended interval dosing method for gentamicin in neonates. Journal of Antimicrobial Chemotherapy 2001;48(6):887-93.

\section{Tantiprabha 2007 \{published data only\}}

Tantiprabha W, Juntarakana S, Chotinaruemol S, Rojanasthien N. Efficacy and safety of gentamicin by interval and intravenous dosage adjustment based on the gestational age in Thai neonates. Journal of the Medical Association of Thailand 2007;90(12):2601-7.

\section{Thingvoll 2008 \{published data only\}}

Thingvoll ES, Guillet R, Caserta M, Dicenzo R. Observational trial of a 48-hour gentamicin dosing regimen derived from Monte Carlo simulations in infants born at less than 28 weeks' gestation. Journal of Pediatrics 2008;153(4):530-4.

\section{Tiwari 2009 \{published data only\}}

Tiwari S, Rehan HS, Chandra J, Mathur NN, Singh V. Efficacy and safety of a single daily dose of gentamicin in hospitalized Indian children: a quasi-randomized trial. Journal of Antimicrobial Chemotherapy 2009;64(5):1096-101.

\section{Yeung 2000 \{published data only\}}

Yeung MY, Smyth JP. Targeting gentamicin concentrations in babies: the younger the baby, the larger the loading dose and the longer the dose interval. Australian Journal of Hospital Pharmacy 2000;30(3):98-101.

\section{Additional references}

\section{Ali 1997}

Ali MZ, Goetz MB. A meta-analysis of the relative efficacy and toxicity of single daily dosing versus multiple daily dosing of aminoglycosides. Clinical Infectious Diseases 1997;24(5):796-809. [PUBMED: 9142772]

\section{Aperia 1981}

Aperia A, Broberger O, Elinder G, Herin P, Zetterstrom R. Postnatal development of renal function in pre-term and fullterm infants. Acta Paediatrica Scandinavia 1981;70(2):183-7. 


\section{Bailey 1997}

Bailey TC, Little JR, Littenberg B, Reichley RM, Dunagan WC. A meta-analysis of extended-interval dosing versus multiple daily dosing of aminoglycosides. Clinical Infectious Diseases 1997;24(5):786-95.

\section{Bajaj 2004}

Bajaj M, Palmer K. Gentamicin usage in newborns--a simple and practical regime. Pharmacy World \& Science 2004;26(4):242-4.

\section{Barza 1996}

Barza M, Ioannidis JP, Cappelleri JC, Lau J. Single or multiple daily doses of aminoglycosides: a meta-analysis. $B M J$ 1996;312(7027):338-45.

\section{Beaubien 1991}

Beaubien AR, Ormsby E, Bayne A, Carrier K, Crossfield G, Downes $\mathrm{M}$, et al. Evidence that amikacin ototoxicity is related to total perilymph area under the concentration-time curve regardless of concentration. Antimicrobial Agents and Chemotherapy 1991;35(6):1070-4.

\section{Begg 2009}

Begg EJ, Vella-Brincat JW, Robertshawe B, McMurtrie MJ, Kirkptrick CM, Darlow B. Eight years' experience of an extendedinterval dosing protocol for gentamicin in neonates. Journal of Antimicrobial Chemotherapy 2009;63(5):1043-9.

\section{Blackburn 1994}

Blackburn ST. Renal function in the neonate. Journal of Perinatal and Neonatal Nursing 1994;8(1):37-47. [PUBMED: 8006805]

\section{Chambers 2001}

Chambers HF. The aminoglycosides. Goodman and Gillman's The pharmacological basis of therapeutics. McGraw-Hill Professional, 2001.

\section{Chattopadhyay 2002}

Chattopadhyay B. Newborns and gentamicin--how much and how often?. Journal of Antimicrobial Chemotherapy 2002;49(1):13-6.

\section{Chuck 2000}

Chuck SK, Raber SR, Rodvold KA, Areff D. National survey of extended-interval aminoglycoside dosing. Clinical Infectious Diseases 2000;30(3):433-9.

\section{Contopoulos-Ioannidis 2004}

Contopoulos-Ioannidis DG, Giotis ND, Baliatsa DV, loannidis JP. Extended-interval aminoglycoside administration for children: a meta-analysis. Pediatrics 2004;114(1):e111-8.

\section{Coscia 2008}

Coscia A, Maiorca D, Martano C, Rossi C, Appino I, Cirina P, et al. Use of netilmicin once or twice daily in preterm newborns: evaluation of nephrotoxicity by urinary alpha 1-microglobulin and retinol binding protein. Journal of Chemotherapy 2008;20(3):324-6.

\section{Craig 1995}

Craig WA. Once-daily versus multiple-daily dosing of aminoglycosides. Journal of Chemotherapy 1995; 7 suppl 2:47-52.

\section{Darmstadt 2007}

Darmstadt GL, Hossain MM, Jana AK, Saha SK, Choi Y, Sridhar S, et al. Determination of extended-interval gentamicin dosing for neonatal patients in developing countries. Pediatric Infectious Disease Journal 2007;26(6):501-7.

\section{Darmstadt 2008}

Darmstadt GL, Miller-Bell M, Batra M, Law P, Law K. Extendedinterval dosing of gentamicin for treatment of neonatal sepsis in developed and developing countries. Journal of Health, Population, and Nutrition 2008;26:163-82.

\section{El-Barbary 2015}

El-Barbary MN, Ismail RIH, Ibrahim AAA. Gentamicin extended interval regimen and ototoxicity in neonates. International Journal of Pediatric Otorhinolaryngology 2015;79(8):1294-8. [PUBMED: 26071016]

\section{Fuchs 2014}

Fuchs A, Guidi M, Giannoni E, Werner D, Buclin T, Widmer N, et al. Population pharmacokinetic study of gentamicin in a large cohort of premature and term neonates. British Journal of Clinical Pharmacology 2014;78(5):1090-101. [PUBMED: 24938850]

\section{Fullas 2011}

Fullas F, Padomek MT, Thieman CJ, Van Gorp AE. Comparative evaluation of six extended-interval gentamicin dosing regimens in premature and full-term neonates. American Journal of Health-System Pharmacy 2011;68(1):52-6. [PUBMED: 21164066]

\section{Gallini 2000}

Gallini F, Maggio L, Romagnoli C, Marrocco G, Tortorolo G. Progression of renal function in preterm neonates with gestational age $<$ or $=32$ weeks. Pediatric Nephrology 2000;15(1-2):119-24.

\section{García 2006}

García B, Barcia E, Pérez F, Molina IT. Population pharmacokinetics of gentamicin in premature newborns. Journal of Antimicrobial Chemotherapy 2006;58(2):372-9. [PUBMED: 16782742]

\section{Giuliano 1986}

Giuliano RA, Verpooten GA, Verbist L, Wedeen RP, De Broe ME. In vivo uptake kinetics of aminoglycosides in the kidney cortex of rats. Journal of Pharmacology and Experimental Therapeutics 1986;236(2):470-5.

\section{GRADEpro [Computer program]}

McMaster University. GRADEpro [www.gradepro.org]. McMaster University, 2014.

\section{Guyatt 2011a}

Guyatt G, Oxman AD, Akl EA, Kunz R, Vist G, Brozek J, et al. GRADE guidelines: 1 . Introduction-GRADE evidence profiles and 
summary of findings tables. Journal of Clinical Epidemiology 2011;64(4):383-94. [PUBMED: 21195583]

\section{Guyatt 2011b}

Guyatt GH, Oxman AD, Vist G, Kunz R, Brozek J, Alonso-Coello P, et al. GRADE guidelines: 4. Rating the quality of evidence-study limitations (risk of bias). Journal of Clinical Epidemiology 2011;64(4):407-15. [PUBMED: 21247734]

\section{Guyatt 2011c}

Guyatt GH, Oxman AD, Kunz R, Brozek J, Alonso-Coello P, Rind $D$, et al. GRADE guidelines: 6 . Rating the quality of evidence--imprecision. Journal of Clinical Epidemiology 2011;64(12):1283-93. [PUBMED: 21839614]

\section{Guyatt 2011d}

Guyatt GH, Oxman AD, Kunz R, Woodcock J, Brozek J, Helfand M, et al. GRADE guidelines: 7 . Rating the quality of evidence--inconsistency. Journal of Clinical Epidemiology 2011;64(12):1294-302. [PUBMED: 21803546]

\section{Guyatt 2011e}

Guyatt GH, Oxman AD, Kunz R, Woodcock J, Brozek J, Helfand $M$, et al. GRADE guidelines: 8 . Rating the quality of evidence--indirectness. Journal of Clinical Epidemiology 2011;64(12):1303-10. [PUBMED: 21802903]

\section{Hatala 1997}

Hatala R, Dinh TT, Cook DJ. Single daily dosing of aminoglycosides in immunocompromised adults: a systematic review. Clinical Infectious Diseases 1997;24(5):810-5.

\section{Hitt 1997}

Hitt CM, Klepser ME, Nightingale CH, Quintiliani R, Nicolau DP. Pharmacoeconomic impact of once-daily aminoglycoside administration. Pharmacotherapy 1997;17(4):810-4.

\section{Kahlmeter 1984}

Kahlmeter G, Dahlager JI. Aminoglycoside toxicity - a review of clinical studies published between 1975 and 1982. Journal of Antimicrobial Chemotherapy 1984;13 Suppl A:9-22.

\section{Kent 2014}

Kent A, Turner MA, Sharland M, Heath PT. Aminoglycoside toxicity in neonates: something to worry about?. Expert Review of Anti-infective Therapy 2014;12(3):319-31. [PUBMED: 24455994]

\section{Knoderer 2003}

Knoderer CA, Everett JA, Buss WF. Clinical issues surrounding once-daily aminoglycoside dosing in children. Pharmacotherapy 2003;23(1):44-56.

\section{Kovarik 1989}

Kovarik JM, Hoepelman IM, Verhoef J. Once-daily aminoglycoside administration: new strategies for an old drug. European Journal of Clinical Microbiology \& Infectious Diseases 1989;8(9):761-9.

\section{König 2015}

König K, Lim A, Miller A, Saker S, Guy KJ, Barfield CP. Gentamicin trough levels using a simplified extended-interval dosing regimen in preterm and term newborn. European Journal of Pediatrics 2014;174(5):669-73. [PUBMED: 25388408]

\section{Lacy 1998}

Lacy MK, Nicolau DP, Nightingale CH, Quintiliani R. The pharmacodynamics of aminoglycosides. Clinical Infectious Diseases 1998;27(1):23-7.

\section{Langlass 1999}

Langlass TM, Mickle TR. Standard gentamicin dosage regimen in neonates. American Journal of Health-System Pharmacy 1999;56(5):440-3.

\section{Lulic-Botica 2013}

Lulic-Botica M, Sheer T, Edwards D, Thomas RL, Natarajan G. Impact of small-for-gestation age (SGA) status on gentamicin pharmacokinetics in neonates. Pediatric Pharmacology 2013;54(1):39-45. [PUBMED: 24122736]

\section{McWilliams 2012}

McWilliams SJ, Antoine DJ, Sabbisetti V, Turner MA, Farragher T, Bonventre JV, et al. Mechanism-based urinary biomarkers to identify the potential for aminoglycoside-induced nephrotoxicity in premature neonates: a proof-of-concept study. PLoS One 2012;7(8):e43809. [PUBMED: 22937100]

\section{Miron 2001}

Miron D. Once daily dosing of gentamicin in infants and children. Pediatric Infectious Disease Journal 2001;20(12):1169-73.

\section{Munckhof 1996}

Munckhof WJ, Grayson ML, Turnidge JD. A meta-analysis of studies on the safety and efficacy of aminoglycosides given either once daily or as divided doses. Journal of Antimicrobial Chemotherapy 1996;37(4):645-63.

\section{Nestaas 2005}

Nestaas E, Bangstad HJ, Sandvik L, Wathne KO. Aminoglycoside extended interval dosing in neonates is safe and effective: a meta-analysis. Archives of disease in childhood. Fetal and neonatal edition 2005;90(4):F294-300. [PUBMED: 15857879]

\section{Nicolau 1996}

Nicolau DP, Wu AH, Finocchiaro S, Udeh E, Chow MS, Quintiliani R, et al. Once-daily aminoglycoside dosing: impact on requests and costs for therapeutic drug monitoring. Therapeutic Drug Monitoring 1996;18(3):263-6.

\section{Nielsen 2009}

Nielsen EI, Sandström M, Honoré PH, Ewald U, Friberg LE. Developmental pharmacokinetics of gentamicin in preterm and term neonates: population modelling of a prospective study. Clinical Pharmacokinetics 2009;48(4):253-63.

\section{Olsen 2004}

Olsen KM, Rudis MI, Rebuck JA, Hara J, Gelmont D, Mehdian R, Nelson C, Rupp ME. Effect of once-daily dosing vs. multiple daily 
dosing of tobramycin on enzyme markers of nephrotoxicity. Critical Care Medicine 2004;32:1678-82.

\section{Pacifici 2009}

Pacifici GM. Clinical pharmacokinetics of aminoglycosides in the neonate: a review. European Journal of Clinical Pharmacology 2009;65:419-27.

\section{Schünemann 2013}

Schünemann H, Brożek J, Guyatt G, Oxman A, editors. GRADE Working Group. GRADE handbook for grading quality of evidence and strength of recommendations. Available from www.guidelinedevelopment.org/handbook updated October 2013.

\section{Setiabudy 2013}

Setiabudy R, Suwento R, Rundjan L, Yasin FH, Louisa M, Dwijayanti A, et al. Lack of relationship between the serum concentration of aminoglycosides and ototoxicity in neonates. International Journal of Clinical Pharmacology and Therapeutics 2013;51(5):401-6. [PUBMED: 23557866]

\section{Sonntag 1996}

Sonntag J, Prankel B, Waltz S. Serum creatinine concentration, urinary creatinine excretion and creatinine clearance during the first 9 weeks in preterm infants with a birth weight below 1500 g. European Journal of Pediatrics 1996;155(9):815-9.

\section{Stoll 1996a}

Stoll BJ, Gordon T, Korones SB, Shankaran S, Tyson JE, Bauer CR, et al. Early-onset sepsis in very low birth weight neonates: a report from the National Institute of Child Health and Human Development Neonatal Research Network. Journal of Pediatrics 1996;129(1):72-80.

\section{Stoll 1996b}

Stoll BJ, Gordon T, Korones SB, Shankaran S, Tyson JE, Bauer CR, et al. Late-onset sepsis in very low birth weight

\section{CHARACTERISTICS OF STUDIES}

Characteristics of included studies [ordered by study ID] neonates: a report from the National Institute of Child Health and Human Development Neonatal Research Network. Journal of Pediatrics 1996;129(1):63-71.

\section{Swan 1997}

Swan SK. Aminoglycoside nephrotoxicity. Seminars in Nephrology 1997;17(1):27-33.

\section{Touw 2009}

Touw DJ, Westerman EM, Sprij AJ. Therapeutic drug monitoring of aminoglycosides in neonates. Clinical Pharmacokinetics 2009;48(2):71-88.

\section{Valitalo 2015}

Valitalo PAJ, van den Anker JN, Allegaert K, de Cock RFW, de Hoong M, Simons SHP, et al. Novel model-based dosing guidelines for gentamicin and tobramycin in preterm and term neonates. Journal of Antimicrobial Chemotherapy 2015;70(7):2074-7. [PUBMED: 25766737]

\section{Vanpée 1993}

Vanpée M, Ergander U, Herin P, Aperia A. Renal function in sick, very low-birth-weight infants. Acta Paediatrica 1993;82(9):714-8.

\section{Verpooten 1989}

Verpooten GA, Giuliano RA, Verbist L, Eestermans G, De Broe ME. Once-daily dosing decreases renal accumulation of gentamicin and netilmicin. Clinical Pharmacology and Therapeutics 1989;45(1):22-7.

\section{References to other published versions of this review \\ Rao 2006}

Rao SC, Ahmed M, Hagan R. One dose per day compared to multiple doses per day of gentamicin for treatment of suspected or proven sepsis in neonates. Cochrane Database of Systematic Reviews 2006, Issue 1. [DOI: 10.1002/14651858.CD005091.pub2]

\section{Agarwal 2002}

\begin{tabular}{ll}
\hline Methods & Randomised controlled trial; single centre; USA \\
\hline Participants & $\mathrm{N}=44$. Infants with $\mathrm{BW} \geq 2500 \mathrm{~g}$, age $\leq 7$ days, Apgar scores of $\geq 5$ at 5 minutes, suspected systemic or \\
focal bacterial infection. Exclusion criteria were history of perinatal asphyxia, shock or cardiorespirato- \\
ry arrest, seizures, anomalies of the kidney or major congenital anomalies incompatible with life and \\
evidence of neuromuscular disorder. 'Once a day' gentamicin: $\mathrm{N}=20$. \\
'Multiple doses a day' gentamicin: $\mathrm{N}=21$. \\
3 infants excluded after enrolment. Mean BW $3302 \pm 674 \mathrm{~g}$ in 'once a day' vs $3387 \pm 526 \mathrm{~g}$ in 'Multiple \\
doses a day' gentamicin group. All infants were enrolled within the first $24 \mathrm{~h}$ after birth. \\
'Once a day' gentamicin group were given gentamicin at $4 \mathrm{mg} / \mathrm{kg} /$ dose once every $24 \mathrm{~h}$. 'Multiple doses \\
a day' gentamicin group were given gentamicin at $2.5 \mathrm{mg} / \mathrm{kg} / \mathrm{dose}$ every $12 \mathrm{~h}$. \\
Gentamicin was infused over a period of 30 min with a metered syringe pump using micropore tubing. \\
All infants were treated concomitantly with ampicillin.
\end{tabular}


Agarwal 2002 (Continued)

Outcomes
Blood for peak serum gentamicin was drawn 30 min after completion of the gentamicin infusion; and for trough concentration, 30 min prior to the start of gentamicin infusion. Trough and peak SGCs drawn with the dose at $48 \mathrm{~h}$ were considered to reflect steady state. Other outcomes that were measured were urine output, serum creatinine, creatinine clearance and hearing screen test prior to discharge.

Notes

\section{Risk of bias}

\begin{tabular}{|c|c|c|}
\hline Bias & Authors' judgement & Support for judgement \\
\hline $\begin{array}{l}\text { Random sequence genera- } \\
\text { tion (selection bias) }\end{array}$ & Low risk & Computer generated numbers \\
\hline $\begin{array}{l}\text { Allocation concealment } \\
\text { (selection bias) }\end{array}$ & Low risk & Using sealed envelopes \\
\hline $\begin{array}{l}\text { Blinding (performance } \\
\text { bias and detection bias) } \\
\text { All outcomes }\end{array}$ & Low risk & $\begin{array}{l}\text { Measurement of peak and trough level are unaffected by knowledge of types } \\
\text { of dosing regimen }\end{array}$ \\
\hline $\begin{array}{l}\text { Incomplete outcome data } \\
\text { (attrition bias) } \\
\text { All outcomes }\end{array}$ & Low risk & Only three infants were excluded after enrolment \\
\hline $\begin{array}{l}\text { Selective reporting (re- } \\
\text { porting bias) }\end{array}$ & Low risk & Predetermined outcome measures reported \\
\hline Other bias & Low risk & Appear to be free of other source of biases \\
\hline
\end{tabular}

Chotigeat 2001

\begin{tabular}{ll}
\hline Methods & Randomised controlled trial; single centre; Thailand \\
\hline Participants & $\mathrm{N}=54$. Infants with $\mathrm{BW} \geq 2000 \mathrm{~g}$, age $<7$ days, gestational age $\geq 34$ weeks, Apgar scores $\geq 4$ at 1 min and \\
6 at 5 min, suspected or proven bacterial infection. Exclusion criteria were allergy to aminoglycoside, \\
congenital anomalies, renal failure and neuromuscular disorder. 'Once a day' gentamicin: $N=27$. \\
'Multiple doses a day' gentamicin: $N=27$. Mean gestational age in 'once a day' group was $38.44 \pm 2.12$ \\
weeks vs $38.37 \pm 2.12$ weeks in 'multiple doses a day' gentamicin group. Mean BW $2924 \pm 597 \mathrm{~g}$ in 'once \\
a day' vs $2987 \pm 656 \mathrm{~g}$ in 'multiple doses a day' gentamicin group. Postnatal age in 'once a day' group \\
was $0.94 \pm 1.22$ days vs $1.43 \pm 1.25$ days in 'multiple doses a day' gentamicin group.
\end{tabular}

Interventions 'Once a day' gentamicin group were given gentamicin at 4 to $5 \mathrm{mg} / \mathrm{kg} / \mathrm{dose}$ once every $24 \mathrm{~h}$. 'Multiple
doses a day' gentamicin group were given gentamicin at 2 to $2.5 \mathrm{mg} / \mathrm{kg} /$ dose every $12 \mathrm{~h}$. Gentamicin was given as a intravenous infusion over $30 \mathrm{~min}$.

Outcomes In 'once a day' gentamicin group blood was drawn for peak serum concentration within 30 min after completion of 3rd dose; and the trough blood sample was drawn within 30 min prior to the 3rd dose. In 'multiple doses a day' gentamicin group blood was drawn for peak serum concentration within 30 minutes after completion of 5th dose; and the trough level blood sample was drawn within 30 min prior to the 5th dose. Other measured outcomes were serum creatinine level on day 1 , day 3 and on the day when gentamicin was discontinued.

Notes Additional information and methodology were clarified by the authors.


Chotigeat 2001 (Continued)

Risk of bias

\begin{tabular}{|c|c|c|}
\hline Bias & Authors' judgement & Support for judgement \\
\hline $\begin{array}{l}\text { Random sequence genera- } \\
\text { tion (selection bias) }\end{array}$ & Unclear risk & Insufficient information about the sequence generation process \\
\hline $\begin{array}{l}\text { Allocation concealment } \\
\text { (selection bias) }\end{array}$ & Low risk & Using sealed envelopes \\
\hline $\begin{array}{l}\text { Blinding (performance } \\
\text { bias and detection bias) } \\
\text { All outcomes }\end{array}$ & Low risk & Outcome assessors were blinded to the intervention \\
\hline $\begin{array}{l}\text { Incomplete outcome data } \\
\text { (attrition bias) } \\
\text { All outcomes }\end{array}$ & Low risk & All 54 eligible infants were included in the analysis \\
\hline $\begin{array}{l}\text { Selective reporting (re- } \\
\text { porting bias) }\end{array}$ & Low risk & Included all prespecified outcomes \\
\hline Other bias & Low risk & Appears to be free of other sources of bias \\
\hline
\end{tabular}

de Alba Romero 1998

\begin{tabular}{ll}
\hline Methods & Randomised controlled trial; single centre; Spain \\
\hline Participants & $\mathrm{N}=80$. Inclusion criteria were $\mathrm{BW} \geq 1200 \mathrm{~g}$, with suspected sepsis. Exclusion criteria were known renal \\
impairment (serum creatinine $>1.2 \mathrm{mg} / \mathrm{dl}$ ), severe neonatal asphyxia and unavailability of blood sam- \\
ples. 'Once a day' gentamicin: $\mathrm{N}=33$. \\
'Multiple doses a day' gentamicin: $\mathrm{N}=32$. Mean gestational age in 'once a day' gentamicin group was \\
$35.5 \pm 3.4$ weeks vs $36.2 \pm 2.9$ weeks in 'multiple doses a day' group. Mean BW in 'once a day' group was \\
$2407 \pm 757 \mathrm{~g}$ vs $2525 \pm 730 \mathrm{~g}$ in 'multiple doses a day' group.
\end{tabular}

Interventions 'Once a day' gentamicin group were given gentamicin at $5 \mathrm{mg} / \mathrm{kg} / \mathrm{dose}$ once every $24 \mathrm{~h}$. 'Multiple doses a day' gentamicin group were given gentamicin at $2.5 \mathrm{mg} / \mathrm{kg} /$ dose every $12 \mathrm{~h}$. Gentamicin was given as intravenous infusion over $60 \mathrm{~min}$. All patients received ampicillin concomitantly.

The peak serum gentamicin level was measured 60 min after completion of the infusion on the 4th
day of treatment. Trough levels were measured immediately before the administration of the dose
on 4th day of treatment. Other outcomes that were measured were urinary N-Acetyl-Beta-D-glu-
cosaminidase:creatinine ratio within the first 2 days and on the 7th day of treatment, serum creatinine
on the 4th day of treatment.

Notes Additional information and methodology were clarified by the authors.

\section{Risk of bias}

\begin{tabular}{lll}
\hline Bias & Authors' judgement & Support for judgement \\
\hline $\begin{array}{l}\text { Random sequence genera- } \\
\text { tion (selection bias) }\end{array}$ & Unclear risk & $\begin{array}{l}\text { "Neonates were randomized to treatment with gentamicin } 5 \mathrm{mg} / \mathrm{kg} \text { either once } \\
\text { daily, or in twice divided doses." } \\
\end{array}$ \\
& \\
& & \\
&
\end{tabular}


de Alba Romero 1998 (Continued)

\begin{tabular}{l}
$\begin{array}{l}\text { Allocation concealment Low risk Using sealed envelopes. } \\
\text { (selection bias) }\end{array}$ \\
\hline
\end{tabular}

\begin{tabular}{lll}
\hline Blinding (performance $\quad$ Low risk $\quad$ Outcome assessors were blinded to the intervention.
\end{tabular}

bias and detection bias)

All outcomes

Incomplete outcome data High risk Only 65 out of the 80 completed the study.
(attrition bias)
All outcomes

\begin{tabular}{lll}
\hline $\begin{array}{l}\text { Selective reporting (re- } \\
\text { porting bias) }\end{array}$ & Unclear risk & $\begin{array}{l}\text { "Clinical efficacy was determined in both groups by clinical evaluation by cus- } \\
\text { tomary evaluations" It is unclear how this was done. }\end{array}$ \\
\hline Other bias & Low risk & Appears to be free of other biases. \\
\hline
\end{tabular}

Hagan 2002

\begin{tabular}{ll}
\hline Methods & Randomised controlled trial; single centre; Australia \\
\hline Participants & $\mathrm{N}=100$. Infants of gestational age more than 33 weeks, age $<7$ days and presumed sepsis. Exclusion \\
criteria were $\mathrm{BW}<2000 \mathrm{~g}$, history of significant asphyxia, congenital malformation and antenatal diag- \\
nosis of renal tract abnormalities. 'Once a day' gentamicin: $\mathrm{N}=46$. \\
'Multiple doses a day' gentamicin : $\mathrm{N}=50$. Median gestational age in 'once a day' group was 38 ( 36 to \\
$40)$ weeks vs 39 ( 35 to 40$)$ weeks in 'multiple doses a day' gentamicin group. Median BW in 'once a day \\
gentamicin' group was $3400(2614,3720) \mathrm{g}$ vs $3130(2560,3750) \mathrm{g}$ in 'multiple doses a day' gentamicin \\
group. Postnatal age in 'once a day' gentamicin group was $0(0,1)$ vs $1(1,2)$ days in 'multiple doses a \\
day' gentamicin group.
\end{tabular}

Interventions

'Once a day' gentamicin group were given gentamicin at $5 \mathrm{mg} / \mathrm{kg} /$ dose once every $24 \mathrm{~h}$. 'Multiple doses a day' gentamicin group were given gentamicin at $2.5 \mathrm{mg} / \mathrm{kg} /$ dose every $18 \mathrm{~h}$. Gentamicin was given either intravenously or intramuscularly.

In 'once a day' gentamicin group blood was drawn for peak serum concentration within 30 minutes af-
ter completion of 3rd dose; and the trough blood sample was drawn within 30 minutes prior to the 3 rd
dose. In 'multiple doses a day' gentamicin group blood was drawn for peak serum concentration within
30 minutes after completion of 3rd dose; and the trough level blood sample was drawn within 30 min-
utes prior to the 3rd dose. Other outcomes that were measured were daily serum creatinine estimation
and otoacoustic emission tests $12 \mathrm{~h}$ before the first dose and after the third dose of gentamicin.

Notes Additional information and methodology were clarified by the authors.

\section{Risk of bias}

\begin{tabular}{lll}
\hline Bias & Authors' judgement & Support for judgement \\
\hline $\begin{array}{l}\text { Random sequence genera- } \\
\text { tion (selection bias) }\end{array}$ & Low risk & Computer-generated numbers \\
\hline $\begin{array}{l}\text { Allocation concealment } \\
\text { (selection bias) }\end{array}$ & Low risk & Using sealed envelopes \\
\hline $\begin{array}{l}\text { Blinding (performance } \\
\text { bias and detection bias) } \\
\text { All outcomes }\end{array}$ & Low risk & $\begin{array}{l}\text { Lab personnel and the people performing hearing tests were blinded to the al- } \\
\text { locations }\end{array}$ \\
\hline
\end{tabular}


Hagan 2002 (Continued)

Incomplete outcome data High risk Gentamicin levels were done in only 65 out of 100 infants. Otoacoustic emis(attrition bias) sion test was done in only 59 infants. Serum creatinine levels were measured All outcomes in 93 infants. Four infants were excluded because of withdrawal of parental consent.

Selective reporting (re- Unclear risk Information available only in abstract form.
porting bias)

Other bias Unclear risk Information available only in abstract form.

\section{Hayani 1997}

\begin{tabular}{|c|c|}
\hline Methods & Randomised controlled trial; single centre, USA \\
\hline Participants & $\begin{array}{l}\mathrm{N}=31 \text {. Infants of gestational age } \geq 34 \text { weeks, age } \leq 24 \mathrm{~h} \text { with suspected sepsis or focal bacterial infec- } \\
\text { tion, } \mathrm{BW} \geq 2000 \mathrm{~g} \text { and Apgar score of } 7 \text { or more at } 5 \text { min. Exclusion criteria were history of cardiopul- } \\
\text { monary arrest, shock, seizures, congenital malformation incompatible with life anomalies of kidney or } \\
\text { ear, or presence of neuromuscular disorder. 'Once a day' gentamicin: } \mathrm{N}=11 \text {. } \\
\text { 'Multiple doses a day' gentamicin: } \mathrm{N}=15 \text {. Overall mean gestational age was } 39.1 \text { ( } 35 \text { to } 41 \text { ) weeks. } \\
\text { Mean BW was } 3200 \text { ( } 2100 \text { to } 4500) \mathrm{g} \text {. }\end{array}$ \\
\hline Interventions & $\begin{array}{l}\text { 'Once a day' gentamicin group were given gentamicin at } 5 \mathrm{mg} / \mathrm{kg} / \text { dose once every } 24 \mathrm{~h} \text {. 'Multiple doses } \\
\text { a day' gentamicin group were given gentamicin at } 2.5 \mathrm{mg} / \mathrm{kg} / \mathrm{dose} \text { every } 12 \mathrm{~h} \text {. Gentamicin was given ei- } \\
\text { ther intravenously or intramuscularly. }\end{array}$ \\
\hline Outcomes & $\begin{array}{l}\text { Serum gentamicin levels were measured on day } 3 \text { of life. Peak serum gentamicin levels were obtained } \\
30 \text { minutes after the end of intravenous dose or } 60 \text { minutes after an intramuscular dose. Trough levels } \\
\text { were obtained } 30 \text { minutes before the dose. Other outcomes measured were urine output, serum creati- } \\
\text { nine, serum electrolytes, blood urea nitrogen, urine sodium, urine creatinine, urine beta- } 2 \text { microglobu- } \\
\text { lin levels and glomerular filtration rate. }\end{array}$ \\
\hline
\end{tabular}

\footnotetext{
Notes
}

\section{Risk of bias}

\begin{tabular}{lll}
\hline Bias & Authors' judgement & Support for judgement \\
\hline $\begin{array}{l}\text { Random sequence genera- } \\
\text { tion (selection bias) }\end{array}$ & Unclear risk & $\begin{array}{l}\text { "subjects were randomly assigned by clinical pharmacist investigators"; insuf- } \\
\text { ficient information about the sequence generation. }\end{array}$ \\
\hline $\begin{array}{l}\text { Allocation concealment } \\
\text { (selection bias) }\end{array}$ & Unclear risk & Method of concealment has not been described. \\
\hline $\begin{array}{l}\text { Blinding (performance } \\
\text { bias and detection bias) }\end{array}$ & Low risk & $\begin{array}{l}\text { Outcomes measures such as peak/trough serum gentamicin levels and creati- } \\
\text { nine levels are not influenced by blinding. }\end{array}$ \\
\hline $\begin{array}{l}\text { Incomplete outcome data } \\
\text { (attrition bias) } \\
\text { All outcomes }\end{array}$ & High risk & $\begin{array}{l}5 \text { patients treated intravenously didn't complete study. 4 infants were dis- } \\
\text { charged home before gentamicin concentration was due for measurement. } 1\end{array}$ \\
\hline $\begin{array}{l}\text { Selective reporting (re- } \\
\text { porting bias) }\end{array}$ & Low risk developed hypotension and shock and was excluded. \\
\hline \begin{tabular}{l} 
Other bias \\
\hline
\end{tabular} & Low risk & All expected outcomes have been reported. \\
\hline
\end{tabular}


Kosalaraksa 2004

\begin{tabular}{ll}
\hline Methods & Randomised controlled trial; single centre; Thailand. \\
\hline Participants & $\mathrm{N}=64$. Inclusion criteria were $\mathrm{BW} \geq 2000 \mathrm{~g}$, age $\leq 7$ days, Apgar score of $>6$ at 5 min and suspected sep- \\
sis. Exclusion criteria were history of perinatal asphyxia, shock, cardiopulmonary arrest, seizure, neuro- \\
muscular disorder or anomalies of kidney or ear. 'Once a day' gentamicin: $\mathrm{N}=33$. \\
'Multiple doses a day' gentamicin: $\mathrm{N}=31$. Mean gestational age in 'once a day' gentamicin group was \\
$38.4 \pm 1.8$ weeks vs $38.6 \pm 2.1$ weeks in 'multiple doses a day' group. Mean BW in 'once a day' group was \\
$3044 \pm 475 \mathrm{~g}$ vs $3036 \pm 497 \mathrm{~g}$ in 'multiple doses a day' group.
\end{tabular}

Interventions 'Once a day' gentamicin group were given gentamicin at $5 \mathrm{mg} / \mathrm{kg} / \mathrm{dose}$ once every $24 \mathrm{~h}$. 'Multiple doses a day' gentamicin group were given gentamicin at $2.5 \mathrm{mg} / \mathrm{kg} /$ dose every $12 \mathrm{~h}$. Gentamicin was given as intravenous infusion over $60 \mathrm{~min}$.

\section{Outcomes}

The peak serum gentamicin level was measured 30 min after infusion (after the 3rd dose in 'once a day' group and the 6th dose in the 'multiple doses a day' group. Trough levels were measured immediately before the 4th dose in 'once a day' group and the 7th dose in the 'multiple doses a day' group. Other outcomes that were measured were urine output, serum creatinine on day 0,3 and 7 or on the discontinuation day.

Notes Additional information and methodology were clarified by the authors.

\section{Risk of bias}

\begin{tabular}{|c|c|c|}
\hline Bias & Authors' judgement & Support for judgement \\
\hline $\begin{array}{l}\text { Random sequence genera- } \\
\text { tion (selection bias) }\end{array}$ & Low risk & Computer-generated random numbers. \\
\hline $\begin{array}{l}\text { Allocation concealment } \\
\text { (selection bias) }\end{array}$ & Low risk & Sealed envelopes. \\
\hline $\begin{array}{l}\text { Blinding (performance } \\
\text { bias and detection bias) } \\
\text { All outcomes }\end{array}$ & Low risk & Outcome assessors were blinded. \\
\hline $\begin{array}{l}\text { Incomplete outcome data } \\
\text { (attrition bias) } \\
\text { All outcomes }\end{array}$ & Low risk & $\begin{array}{l}\text { Only } 3 \text { out of the } 64 \text { study infants did not have blood levels of gentamicin mea- } \\
\text { sured. }\end{array}$ \\
\hline
\end{tabular}

\begin{tabular}{|c|c|c|}
\hline $\begin{array}{l}\text { Selective reporting (re- } \\
\text { porting bias) }\end{array}$ & High risk & $\begin{array}{l}\text { "serum creatinine was measured on days } 0,3 \text { and } 7 \text { or discontinuation day": } \\
\text { statistical method to compare was not pre-specified. }\end{array}$ \\
\hline & & $\begin{array}{l}\text { "The authors evaluated the clinical response using inclusion point of "im- } \\
\text { provement within } 72 \text { hours of treatment": method to define "improvement } \\
\text { within } 72 \text { hour of treatment" not pre-defined. }\end{array}$ \\
\hline
\end{tabular}

Other bias Low risk Appears to be free of other sources of bias.

Krishnan 1997

\begin{tabular}{ll}
\hline Methods & Randomised controlled trial; single centre; India \\
\hline Participants & $\mathrm{N}=18$. Inclusion criteria were neonates requiring gentamicin therapy as per unit protocol, 32 to 36 \\
& weeks' gestation, $<96 \mathrm{~h}$ of age, and serum creatinine $<1 \mathrm{mg} / \mathrm{dl}$. 'Once a day' gentamicin: $\mathrm{N}=9$.
\end{tabular}


Krishnan 1997 (Continued)

Multiple doses a day' gentamicin: $\mathrm{N}=9$. Mean gestational age was $34.1 \pm 1.5$ weeks in 'once a day' gentamicin group and $34.0 \pm 1.9$ weeks in 'multiple doses a day' group. Mean BW in 'once a day' group was $1940 \pm 510 \mathrm{~g}$ and $1739 \pm 527 \mathrm{~g}$ in 'multiple doses a day' group.

\begin{tabular}{|c|c|}
\hline Interventions & $\begin{array}{l}\text { 'Once a day' gentamicin group were given gentamicin at } 4 \mathrm{mg} / \mathrm{kg} / \text { dose once every } 24 \mathrm{~h} \text {. 'Multiple doses } \\
\text { a day' gentamicin group were given gentamicin at } 2.5 \mathrm{mg} / \mathrm{kg} / \mathrm{dose} \text { every } 12 \mathrm{~h} \text {. Gentamicin was given as } \\
\text { 1-min bolus intravenously followed by normal saline flush of } 0.5 \mathrm{ml} \text {. }\end{array}$ \\
\hline
\end{tabular}

Outcomes Peak levels were collected 1 hour after the first dose and the dose given at $48 \mathrm{~h}$. Trough levels were collected just prior to the dose of gentamicin due at $48 \mathrm{~h}$ after the start of the therapy. Other outcomes measured were serum creatinine.

Notes Additional information and methodology were clarified by the authors.

\section{Risk of bias}

\begin{tabular}{lll}
\hline Bias & Authors' judgement & Support for judgement \\
\hline $\begin{array}{l}\text { Random sequence genera- } \\
\text { tion (selection bias) }\end{array}$ & Low risk & Computer-generated random numbers. \\
\hline $\begin{array}{l}\text { Allocation concealment } \\
\text { (selection bias) }\end{array}$ & Low risk & Sealed envelopes \\
\hline $\begin{array}{l}\text { Blinding (performance } \\
\text { bias and detection bias) } \\
\text { All outcomes }\end{array}$ & Low risk & Outcome assessors were blinded. \\
\hline $\begin{array}{l}\text { Incomplete outcome data } \\
\text { (attrition bias) } \\
\text { All outcomes }\end{array}$ & Low risk & All 18 neonates were included in the results. \\
\hline $\begin{array}{l}\text { Selective reporting (re- } \\
\text { porting bias) }\end{array}$ & High risk & $\begin{array}{l}\text { "There was no nephrotoxicity in either groups at the end of therapy." There } \\
\text { was no pre-specified analysis method to measure nephrotoxicity in the } \\
\text { methodology. }\end{array}$ \\
\hline \begin{tabular}{l} 
Other bias \\
\hline
\end{tabular} & Low risk & \begin{tabular}{l} 
Appears to be free of other sources of bias. \\
\hline
\end{tabular} \\
\hline
\end{tabular}

Miron 2003

\begin{tabular}{ll}
\hline Methods & Quasi-randomised controlled trial; single centre; Israel. \\
\hline Participants & $\begin{array}{l}\mathrm{N}=35 . \text { Inclusion criteria were } \mathrm{BW} \geq 1500 \mathrm{~g} \text {, age } \leq 24 \mathrm{~h} \text {, gestational age } 32 \text { to } 37 \text { weeks and suspected } \\
\text { sepsis. Exclusion criteria were shock, impaired renal function and known kidney, ear or heart malfor- } \\
\text { mations and metabolic disease. 'Once a day' gentamicin: } \mathrm{N}=17 . \\
\text { 'Multiple doses a day' gentamicin: } \mathrm{N}=18 .\end{array}$ \\
\hline Interventions & $\begin{array}{l}\text { 'Once a day' gentamicin group were given gentamicin at } 5 \mathrm{mg} / \mathrm{kg} / \mathrm{dose} \text { once every } 24 \mathrm{~h} . \text { ' Multiple doses } \\
\text { a day' gentamicin group were given gentamicin at } 2.5 \mathrm{mg} / \mathrm{kg} / \mathrm{dose} \text { every } 12 \mathrm{~h} .\end{array}$ \\
\hline Outcomes & $\begin{array}{l}\text { The serum gentamicin levels were measured at } 72 \mathrm{~h} \text { to } 96 \mathrm{~h} \text { of therapy. The peak serum gentamicin lev- } \\
\text { el was measured } 30 \text { minutes after infusion. Trough levels were measured } 30 \text { min before the next dose. } \\
\text { Other outcomes that were measured were serum and urine creatinine and sodium concentrations, uri- } \\
\text { nary lysozyme excretion, glomerular filtration rate and fractional excretion of sodium at } 72 \mathrm{~h} \text { to } 96 \mathrm{~h} \text { of } \\
\text { therapy. Pure tone audiometric evaluation was performed at } 1 \text { to } 2 \text { months of age. Brainstem-evoked } \\
\text { response audiometry was performed if there was suspicion on pure tone audiometry. }\end{array}$
\end{tabular}


Miron 2003 (Continued)

Notes Additional information and methodology were clarified by the authors.

\section{Risk of bias}

\begin{tabular}{|c|c|c|}
\hline Bias & Authors' judgement & Support for judgement \\
\hline $\begin{array}{l}\text { Random sequence genera- } \\
\text { tion (selection bias) }\end{array}$ & High risk & $\begin{array}{l}\text { Allocation based on the month of the year: single dose a day in January to } \\
\text { March 1998; multiple doses a day in April/May1998. }\end{array}$ \\
\hline $\begin{array}{l}\text { Allocation concealment } \\
\text { (selection bias) }\end{array}$ & High risk & Allocation concealment was not achieved. \\
\hline $\begin{array}{l}\text { Blinding (performance } \\
\text { bias and detection bias) } \\
\text { All outcomes }\end{array}$ & Low risk & Lab personnel and statisticians were blinded to the intervention. \\
\hline $\begin{array}{l}\text { Incomplete outcome data } \\
\text { (attrition bias) } \\
\text { All outcomes }\end{array}$ & Low risk & No missing outcome data. \\
\hline $\begin{array}{l}\text { Selective reporting (re- } \\
\text { porting bias) }\end{array}$ & Low risk & All prespecified outcomes reported. \\
\hline Other bias & Unclear risk & Appears to be free of other sources of bias \\
\hline
\end{tabular}

\section{Skopnik 1992}

\begin{tabular}{ll}
\hline Methods & Randomised controlled trial; single centre; Germany \\
\hline Participants & $\mathrm{N}=20$. Inclusion criteria were neonates with pneumonia, meconium aspiration, suspected bacterial \\
sepsis, and premature rupture of membranes $>36 \mathrm{~h}$ before delivery. Exclusion criteria were gestational \\
age $<37$ weeks, $\mathrm{BW}<2500 \mathrm{~g}$, Apgar score of $\leq 4$ at 1 minute and $\leq 6$ at 5 minutes, serum creatinine $>85$ \\
micromol/l and those requiring diuretics during the course of treatment and those who were exposed \\
to aminoglycoside prenatally. 'Once a day' gentamicin: $\mathrm{N}=10$. \\
'Multiple doses a day' gentamicin: $\mathrm{N}=10$. Mean gestational age in 'once a day' gentamicin group was \\
$39.5 \pm 1.4$ weeks vs $40.3 \pm 0.8$ weeks in 'multiple doses a day' group. Mean BW in 'once a day' group was \\
$3300 \pm 600 \mathrm{~g}$ vs $3800 \pm 600 \mathrm{~g}$ in 'multiple doses a day' group.
\end{tabular}

Interventions 'Once a day' gentamicin group were given gentamicin at $4 \mathrm{mg} / \mathrm{kg} / \mathrm{dose}$ once every $24 \mathrm{~h}$. 'Multiple doses a day' gentamicin group were given gentamicin at $2 \mathrm{mg} / \mathrm{kg} /$ dose every $12 \mathrm{~h}$. Gentamicin was given as intravenous infusion over $30 \mathrm{~min}$. All infants were treated with ampicillin concomitantly.

The pharmacokinetic profile of gentamicin was determined on the fourth day of treatment. Outcomes
measured were peak levels, trough levels and area under the concentration time curves, urinary excre-
tion of alanine aminopeptidase as a marker of nephrotoxicity.
tion of alanine aminopeptidase as a marker of nephrotoxicity.

Notes Additional information and methodology were clarified by the authors.

\section{Risk of bias}

\section{Bias}

Random sequence genera- Low risk tion (selection bias)

\section{Authors' judgement Support for judgement}

Computer-generated random numbers. 
Skopnik 1992 (Continued)

$\begin{aligned} & \text { Allocation concealment } \\ & \text { (selection bias) }\end{aligned} \quad$ Unclear risk Insufficient information to allow a definite judgement.

Blinding (performance Low risk Outcome measures unlikely to influence outcome measures.

bias and detection bias)

All outcomes

Incomplete outcome data Low risk No missing outcome data.
(attrition bias)

(attrition bias)

All outcomes

Selective reporting (re- Low risk All prespecified outcomes reported.

porting bias)

Other bias Low risk Appears to be free of other biases.

Solomon 1999

\begin{tabular}{ll}
\hline Methods & Randomised controlled trial; single centre; India \\
\hline Participants & $\mathrm{N}=73$. Inclusion criteria were gestational age $\geq 32$ weeks, with suspected or confirmed sepsis. 48 term \\
& and 25 preterm infants were included. 'Once a day' gentamicin: $\mathrm{N}=37$. \\
'Multiple doses a day' gentamicin: $\mathrm{N}=36$. Among preterm infants, the mean gestational age in 'once a \\
day' gentamicin group was $34.2 \pm 1.1$ weeks vs $33.0 \pm 0.7$ weeks in 'multiple doses a day' group. Mean \\
BW in 'once a day' group was $1919 \pm 255 \mathrm{~g}$ vs $1830 \pm 184 \mathrm{~g}$ in 'multiple doses a day' group. Among term \\
infants, the mean gestational age in 'once a day' group was $39.2 \pm 1.4$ weeks vs $39 \pm 1.3$ weeks in 'multi- \\
ple doses a day' group. Mean BW in 'once a day' group was $2935 \pm 552 \mathrm{~g}$ vs $2968 \pm 613 \mathrm{~g}$ in 'multiple dos- \\
es a day' group.
\end{tabular}

Interventions

'Once a day' gentamicin group were given gentamicin at $4 \mathrm{mg} / \mathrm{kg} /$ dose once every $24 \mathrm{~h}$. 'Multiple doses a day' gentamicin group were given gentamicin at $2.5 \mathrm{mg} / \mathrm{kg} /$ dose every $12 \mathrm{~h}$. Gentamicin was given as intravenous infusion over $30 \mathrm{~min}$ followed by normal saline flush.

The peak serum gentamicin level was measured 60 min after completion of the infusion of the $2 \mathrm{nd}$
dose of gentamicin. Trough levels were measured 30 min before the administration of the 2 nd dose of
gentamicin.

Notes

Risk of bias

\begin{tabular}{|c|c|c|}
\hline Bias & Authors' judgement & Support for judgement \\
\hline $\begin{array}{l}\text { Random sequence genera- } \\
\text { tion (selection bias) }\end{array}$ & Unclear risk & $\begin{array}{l}\text { "Babies in each groups were randomly assigned to receive injection gentam- } \\
\text { icin at a dose of..." }\end{array}$ \\
\hline $\begin{array}{l}\text { Allocation concealment } \\
\text { (selection bias) }\end{array}$ & Unclear risk & No method of concealment described. \\
\hline $\begin{array}{l}\text { Blinding (performance } \\
\text { bias and detection bias) } \\
\text { All outcomes }\end{array}$ & Low risk & Outcome measurements unlikely to be effected by blinding. \\
\hline $\begin{array}{l}\text { Incomplete outcome data } \\
\text { (attrition bias) }\end{array}$ & Low risk & All 73 patients analysed. \\
\hline
\end{tabular}

One dose per day compared to multiple doses per day of gentamicin for treatment of suspected or proven sepsis in neonates (Review) 
Solomon 1999 (Continued)

All outcomes

Selective reporting (re- Low risk Pre-specified primary outcomes have been reported.

porting bias)

Other bias Low risk Appears to be free of other biases.

Thureen 1999

\begin{tabular}{ll} 
Methods & Quasi-randomised controlled trial; single centre; USA. Dose schedules were rotated on a monthly basis. \\
\hline Participants & $\mathrm{N}=55$. Inclusion criteria were gestational age $\geq 34$ weeks, postnatal age $<7$ days, Apgar scores of $>4$ at \\
1 minute and $>6$ at 5 minutes respectively, urine output $>0.5 \mathrm{ml} / \mathrm{kg} / \mathrm{hour}$ in the first $24 \mathrm{~h}$ of life or $>1$ \\
$\mathrm{ml} / \mathrm{kg} / \mathrm{h}$ in the second $24 \mathrm{~h}$ of life and absence of inotropic support. 'Once a day' gentamicin: $\mathrm{N}=27$. \\
'Multiple doses a day' gentamicin: $\mathrm{N}=28$. Mean gestational age in 'once a day' gentamicin group was \\
$37.8 \pm 2.1$ weeks vs $36.9 \pm 2.6$ weeks in 'multiple doses a day' group. Mean BW in 'once a day' group was \\
$2831 \pm 613 \mathrm{~g}$ vs $2795 \pm 714 \mathrm{~g}$ in 'multiple doses a day' group.
\end{tabular}

Interventions $\begin{aligned} & \text { 'Once a day' gentamicin group were given gentamicin at } 4 \mathrm{mg} / \mathrm{kg} / \text { dose once every } 24 \mathrm{~h} \text {. 'Multiple doses } \\ & \text { a day' gentamicin group were given gentamicin at } 2.5 \mathrm{mg} / \mathrm{kg} / \mathrm{dose} \text { every } 12 \mathrm{~h} \text {. Gentamicin was given as } \\ & \text { intravenous infusion over } 30 \mathrm{~min} \text {. All patients received ampicillin concomitantly. }\end{aligned}$

Outcomes The peak serum gentamicin level was measured $30 \mathrm{~min}$ after completion of the infusion on day three of therapy (fifth dose of 'multiple doses a day' and third dose of 'once a day' gentamicin group). Trough levels were measured immediately before the administration of the dose on day three of therapy (fifth dose of 'multiple doses a day' and third dose of 'once a day' gentamicin group). Other outcome measured was cost of therapy.

Notes Additional information and methodology were clarified by the authors.

\section{Risk of bias}

\begin{tabular}{|c|c|c|}
\hline Bias & Authors' judgement & Support for judgement \\
\hline $\begin{array}{l}\text { Random sequence genera- } \\
\text { tion (selection bias) }\end{array}$ & High risk & Quasi-randomised trial; dose schedules were rotated on a monthly basis. \\
\hline $\begin{array}{l}\text { Allocation concealment } \\
\text { (selection bias) }\end{array}$ & High risk & Allocation to a particular study group was open to investigators. \\
\hline $\begin{array}{l}\text { Blinding (performance } \\
\text { bias and detection bias) } \\
\text { All outcomes }\end{array}$ & Low risk & $\begin{array}{l}\text { "Cost of labor was determined by time-in motion observations of gentam- } \\
\text { icin-associated tasks". Lack of blinding may have influenced cost-effectiveness } \\
\text { analyses. But serum gentamicin concentration measurement unaffected by } \\
\text { blinding. }\end{array}$ \\
\hline $\begin{array}{l}\text { Incomplete outcome data } \\
\text { (attrition bias) } \\
\text { All outcomes }\end{array}$ & Low risk & All 55 patients analysed. \\
\hline $\begin{array}{l}\text { Selective reporting (re- } \\
\text { porting bias) }\end{array}$ & Low risk & All prespecified primary outcomes reported. \\
\hline Other bias & Low risk & Appears to be free of other biases. \\
\hline
\end{tabular}

BW = birth weight

One dose per day compared to multiple doses per day of gentamicin for treatment of suspected or proven sepsis in neonates (Review) 
$h=$ hour

$\min =$ minute

vs $=$ versus

Characteristics of excluded studies [ordered by study ID]

\begin{tabular}{ll}
\hline Study & Reason for exclusion \\
\hline Alsaedi 2003 & $\begin{array}{l}\text { Not an RCT. The controls were historical. 'Multiple doses a day' regimen was practised between No- } \\
\text { vember } 1999 \text { to October } 2000 \text { and 'once a day' gentamicin regimen was used between November } \\
2000 \text { and October 2002. Information from the first period was gathered from retrospective chart re- } \\
\text { views. }\end{array}$
\end{tabular}

\begin{tabular}{ll}
\hline Alshaikh 2012 & $\begin{array}{l}\text { Not an RCT. This was an Observational study comparing extended interval dosing to historical data } \\
\text { of multiple dosing control group. }\end{array}$ \\
\hline Davies 1998 & $\begin{array}{l}\text { Not an RCT. It was a retrospective study of neonates born in the last half of } 1995 \text { who received gen- } \\
\text { tamicin. }\end{array}$
\end{tabular}

English 2004 . Loading dose of $8 \mathrm{mg} / \mathrm{kg}$ was used in 'once a day' gentamicin regimen whereas no loading
dose was used in 'multiple doses a day' regimen.

Fjalstad $2014 \quad$ Not an RCT. This was an observational study comparing 24 hourly, 36 hourly and 48 hourly dosing intervals.
Gonzalez Santacruz M 2008 Not an RCT. This was a retrospective study comparing the outcomes prior to and after implementa- tion of the change in protocol to 'once a day' regimen.

$\begin{array}{ll}\text { Hagen } 2009 & \text { Not an RCT. This was a retrospective comparative study of two periods involving change in regi- } \\ \text { men. }\end{array}$

$\begin{array}{ll}\text { Hansen } 2003 & \text { Not an RCT. It was an audit of use of once-daily gentamicin for preterm and term infants for the pe- } \\ \text { riod } 31 \text { March } 1999 \text { and } 31 \text { December } 2000\end{array}$

\begin{tabular}{ll}
\hline Hiltron 2010 & Not an RCT. This was a retrospective observational study. \\
\hline Hoff 2009 & $\begin{array}{l}\text { Not an RCT. This was a retrospective study comparing 24-hourly gentamicin to 48-hourly dose of } \\
\text { gentamicin. }\end{array}$
\end{tabular}

\begin{tabular}{ll}
\hline Hossain 2009 & Not an RCT. This was an observational study comparing 24-hourly and 48-hourly dosing intervals. \\
\hline Isemann 1996 & $\begin{array}{l}\text { RCT. Compared the peak and trough concentrations of gentamicin in neonates after a standard } \\
\text { dose or a loading dose on the first day of life. }\end{array}$ \\
\hline Kaspers 1998 & $\begin{array}{l}\text { Not an RCT. It was a retrospective and subsequently prospective descriptive study. Newborn in- } \\
\text { fants were administered gentamicin twice a day in the year } 1995 \text { and their results were analysed } \\
\text { retrospectively. Infants were administered gentamicin once a day in the year } 1996 .\end{array}$
\end{tabular}

\begin{tabular}{ll}
\hline Krishnamoorthy 2013 & Not an RCT. This was a retrospective study comparing 24-hourly to 36-hourly dosing intervals. \\
\hline Lanao 2004 & Not an RCT. Retrospective study \\
\hline Low 2015 & Not an RCT. Observational study comparing 24-hourly to 36-hourly dosing intervals. \\
\hline Lundergan 1999 & Not an RCT. Information from controls were derived from retrospective chart review. \\
\hline Martinkova 2010 & $\begin{array}{l}\text { Not an RCT. This was an observational study comparing 48-hourly, 36-hourly and 24-hourly dosing } \\
\text { intervals. }\end{array}$
\end{tabular}




\begin{tabular}{|c|c|}
\hline Study & Reason for exclusion \\
\hline Mercado 2004 & $\begin{array}{l}\text { RCT. Compared 'once a day' to 'extended interval dosing of once in } 48 \text { hours' regimen of gentam- } \\
\text { icin. }\end{array}$ \\
\hline Rastogi 2002 & RCT. 'Once a day' gentamicin regimen was compared to 'once in 48 hours' regimen of gentamicin. \\
\hline Semchuk 1995 & RCT. Use of loading dose was compared to the regimen of no loading dose of gentamicin. \\
\hline Serane 2009 & $\begin{array}{l}\text { Not an RCT. Only patients who received 'once a day' dosage were studied. There was no compari- } \\
\text { son group. }\end{array}$ \\
\hline Skopnik 1995 & Not an RCT. It was an audit. \\
\hline Stickland 2001 & $\begin{array}{l}\text { Not an RCT. It was an audit of the use of extended interval dosing method for gentamicin in } \\
\text { neonates. }\end{array}$ \\
\hline Tantiprabha 2007 & Not an RCT. Only patients who received 'once a day' dosage were studied. \\
\hline Thingvoll 2008 & Not an RCT. This was an observational study. Participants were less than 28 weeks of gestation. \\
\hline Tiwari 2009 & $\begin{array}{l}\text { Data from } 0 \text { to } 12 \text { year age group were published. Relevant data from neonatal population could } \\
\text { not be derived from the published article. We made } 3 \text { attempts to obtain relevant data from the au- } \\
\text { thors, but authors did not respond. }\end{array}$ \\
\hline Yeung 2000 & $\begin{array}{l}\text { Not an RCT. This was an observational study including 'once a day' dosing with no comparison } \\
\text { group. }\end{array}$ \\
\hline
\end{tabular}

DATA AND ANALYSES

Comparison 1. All studies comparing 'once a day' versus 'multiple doses a day' regimen

\begin{tabular}{|c|c|c|c|c|}
\hline Outcome or subgroup title & No. of studies & $\begin{array}{l}\text { No. of partici- } \\
\text { pants }\end{array}$ & Statistical method & Effect size \\
\hline 1 Clearance of proven sepsis & 3 & 37 & $\begin{array}{l}\text { Risk Difference (M-H, Fixed, 95\% } \\
\mathrm{CI})\end{array}$ & $0.0[-0.19,0.19]$ \\
\hline $\begin{array}{l}2 \text { Failure to achieve peak levels } \\
\text { of at least } 5 \text { microgram } / \mathrm{ml}\end{array}$ & 9 & 422 & Risk Ratio (M-H, Fixed, 95\% Cl) & $0.22[0.11,0.47]$ \\
\hline $\begin{array}{l}3 \text { Failure to achieve trough lev- } \\
\text { els of }<=2 \text { microgram } / \mathrm{ml}\end{array}$ & 11 & 503 & Risk Ratio (M-H, Fixed, 95\% Cl) & $0.38[0.27,0.55]$ \\
\hline 4 Ototoxicity & 5 & 214 & Risk Ratio (M-H, Fixed, 95\% Cl) & $1.69[0.18,16.25]$ \\
\hline 5 Nephrotoxicity & 8 & 348 & Risk Ratio (M-H, Fixed, 95\% Cl) & $0.0[0.0,0.0]$ \\
\hline 6 Treatment failure & 3 & 37 & $\begin{array}{l}\text { Risk Difference (M-H, Fixed, 95\% } \\
\mathrm{Cl})\end{array}$ & $0.0[-0.19,0.19]$ \\
\hline 7 Actual peak levels ( $\mu \mathrm{g} / \mathrm{ml}$ ) & 10 & 440 & $\begin{array}{l}\text { Mean Difference (IV, Fixed, 95\% } \\
\mathrm{CI})\end{array}$ & $2.58[2.26,2.89]$ \\
\hline
\end{tabular}




\begin{tabular}{lllll}
\hline Outcome or subgroup title & No. of studies & $\begin{array}{l}\text { No. of partici- } \\
\text { pants }\end{array}$ & Statistical method & Effect size \\
\hline 8 Actual trough levels $(\mu \mathrm{g} / \mathrm{ml})$. & 10 & 440 & $\begin{array}{l}\text { Mean Difference (IV, Fixed, } 95 \% \\
\text { Cl) }\end{array}$ & $-0.57[-0.69,-0.44]$ \\
\hline
\end{tabular}

Analysis 1.1. Comparison 1 All studies comparing 'once a day' versus 'multiple doses a day' regimen, Outcome 1 Clearance of proven sepsis.

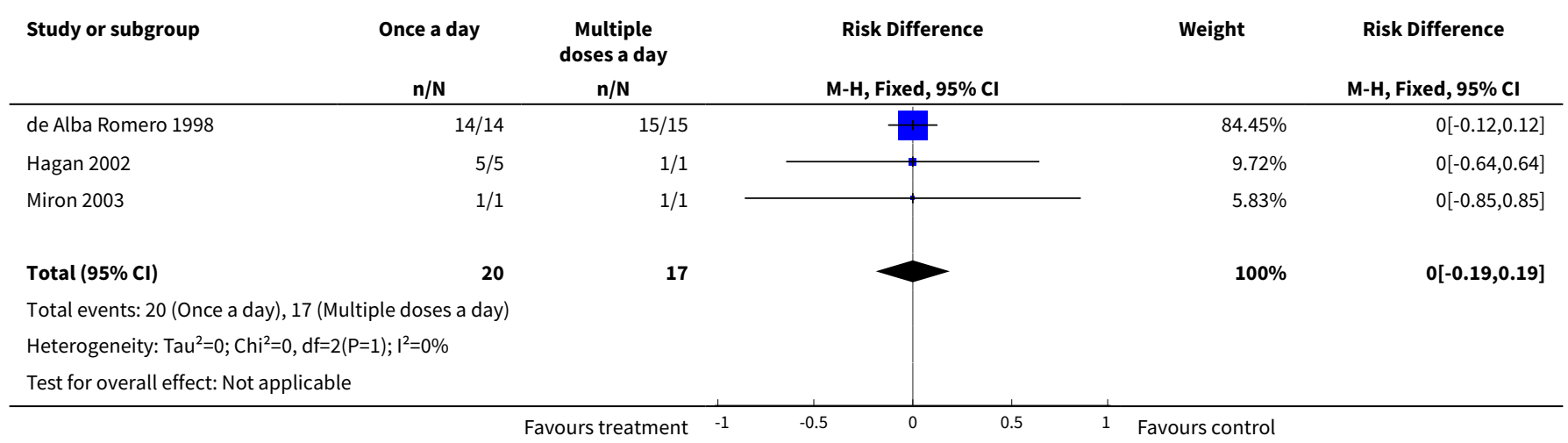

Analysis 1.2. Comparison 1 All studies comparing 'once a day' versus 'multiple doses a day' regimen, Outcome 2 Failure to achieve peak levels of at least 5 microgram $/ \mathrm{ml}$.




Analysis 1.3. Comparison 1 All studies comparing 'once a day' versus 'multiple doses a day' regimen, Outcome 3 Failure to achieve trough levels of $<=2 \mathrm{microgram} / \mathrm{ml}$.

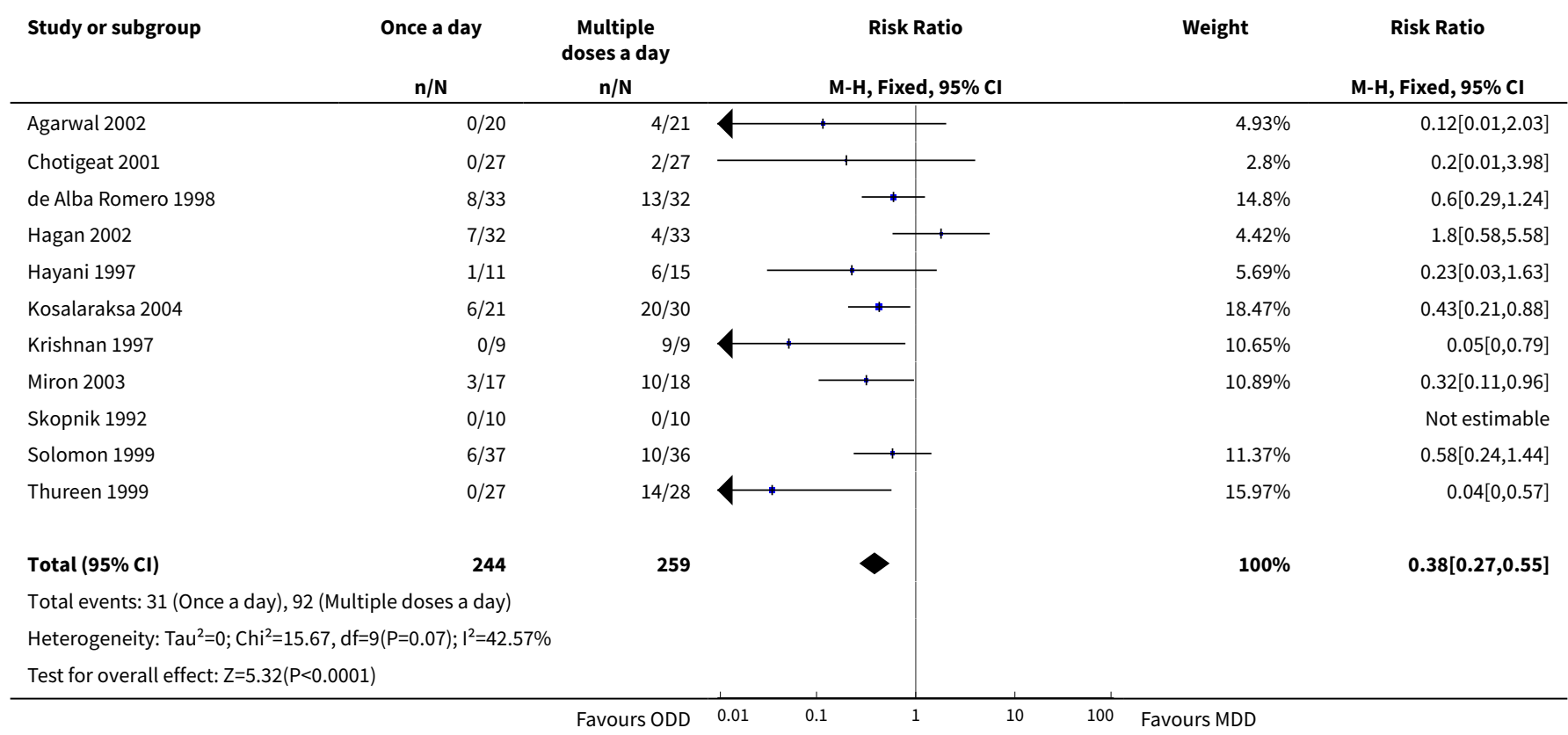

Analysis 1.4. Comparison 1 All studies comparing 'once a day' versus 'multiple doses a day' regimen, Outcome 4 Ototoxicity.

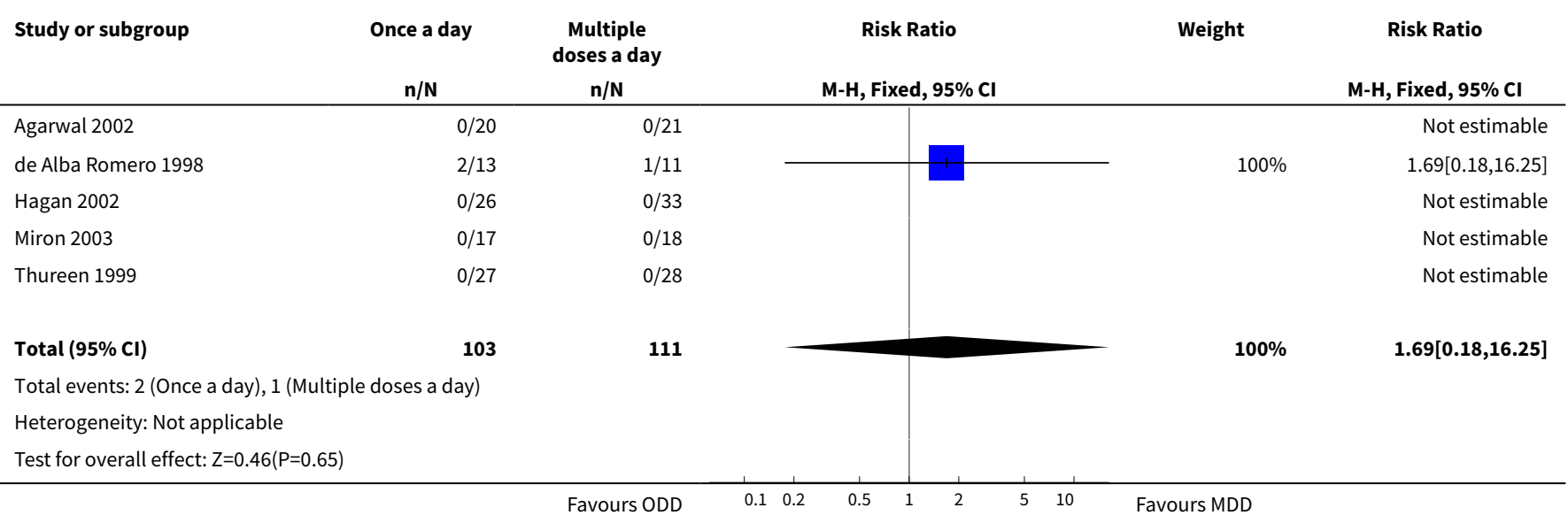

Analysis 1.5. Comparison 1 All studies comparing 'once a day' versus 'multiple doses a day' regimen, Outcome 5 Nephrotoxicity.

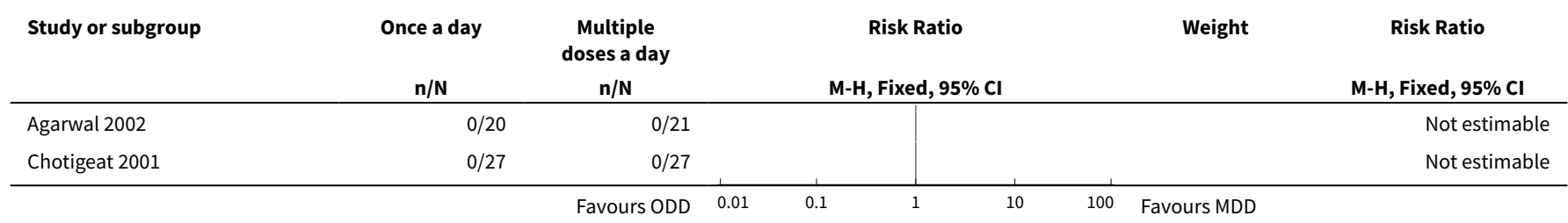






Analysis 1.6. Comparison 1 All studies comparing 'once a day' versus 'multiple doses a day' regimen, Outcome 6 Treatment failure.

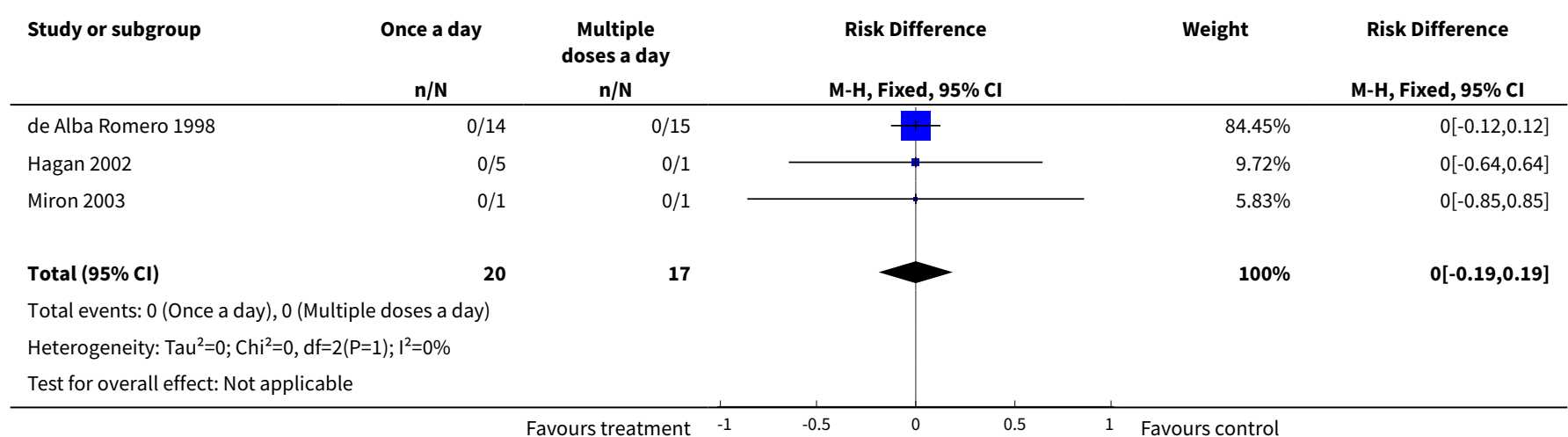

Analysis 1.7. Comparison 1 All studies comparing 'once a day' versus 'multiple doses a day' regimen, Outcome 7 Actual peak levels $(\mu \mathrm{g} / \mathrm{ml})$.

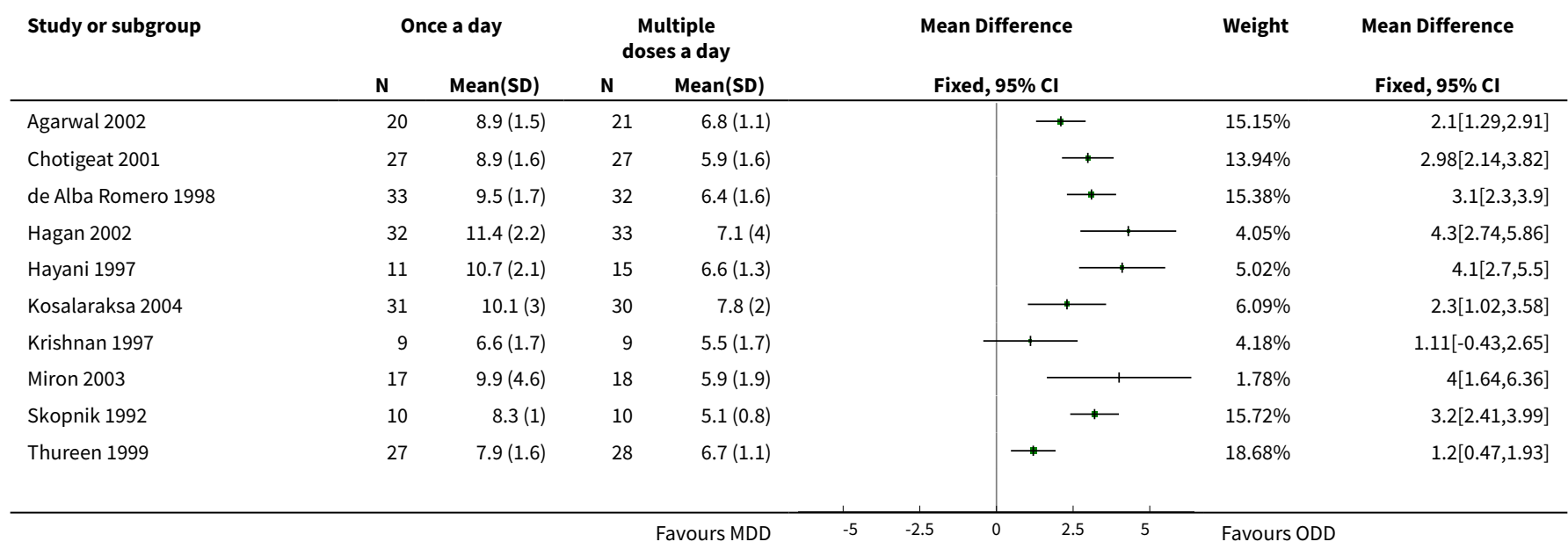




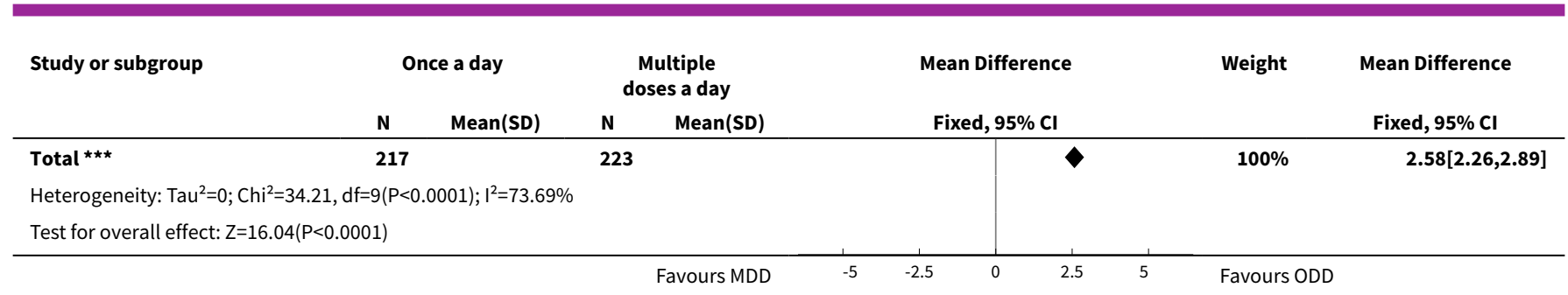

Analysis 1.8. Comparison 1 All studies comparing 'once a day' versus 'multiple doses a day' regimen, Outcome 8 Actual trough levels $(\mu \mathrm{g} / \mathrm{ml})$..



\section{APPENDICES}

\section{Appendix 1. Risk of Bias tool}

The following items were entered into the 'Risk of bias' table:

(1) Sequence generation (checking for possible selection bias). Was the allocation sequence adequately generated?

For each included study, we categorized the method used to generate the allocation sequence as:

- adequate (low risk of bias) (any truly random process e.g. random number table; computer random number generator);

- inadequate (high risk of bias) (any non random process e.g. odd or even date of birth; hospital or clinic record number); - unclear risk of bias.

(2) Allocation concealment (checking for possible selection bias). Was allocation adequately concealed?

For each included study, we categorized the method used to conceal the allocation sequence as:

- adequate (low risk of bias) (e.g. telephone or central randomisation; consecutively numbered sealed opaque envelopes);

- inadequate (high risk of bias) (open random allocation; unsealed or non-opaque envelopes, alternation; date of birth); - unclear risk of bias. 
(3) Blinding (checking for possible performance bias). Was knowledge of the allocated intervention adequately prevented during the study? At study entry? At the time of outcome assessment?

For each included study, we categorized the methods used to blind study participants and personnel from knowledge of which intervention a participant received. Blinding was assessed separately for different outcomes or classes of outcomes. We categorized the methods as:

- adequate (low risk of bias), inadequate (high risk of bias) or unclear risk of bias for participants;

- adequate (low risk of bias), inadequate (high risk of bias) or unclear risk of bias for personnel;

- adequate (low risk of bias), inadequate (high risk of bias) or unclear risk of bias for outcome assessors.

In some situations there may be partial blinding e.g. where outcomes are self-reported by unblinded participants but they are recorded by blinded personnel without knowledge of group assignment. Where needed "partial" was added to the list of options for assessing quality of blinding.

(4) Incomplete outcome data (checking for possible attrition bias through withdrawals, dropouts, protocol deviations). Were incomplete outcome data adequately addressed?

For each included study and for each outcome, we described the completeness of data including attrition and exclusions from the analysis. We noted whether attrition and exclusions were reported, the numbers included in the analysis at each stage (compared with the total randomised participants), reasons for attrition or exclusion where reported, and whether missing data were balanced across groups or were related to outcomes. Where sufficient information was reported or supplied by the trial authors, we re-included missing data in the analyses. We categorized the methods as:

- adequate (low risk of bias) $(<20 \%$ missing data);

- inadequate (high risk of bias) $(\geq 20 \%$ missing data):

- unclear risk of bias.

(5) Selective reporting bias. Are reports of the study free of suggestion of selective outcome reporting?

For each included study, we described how we investigated the possibility of selective outcome reporting bias and what we found. We assessed the methods as:

- adequate (where it is clear that all of the study's pre-specified outcomes and all expected outcomes of interest to the review have been reported);

- inadequate (where not all the study's pre-specified outcomes have been reported; one or more reported primary outcomes were not prespecified; outcomes of interest are reported incompletely and so cannot be used; study fails to include results of a key outcome that would have been expected to have been reported);

- unclear risk of bias.

(6) Other sources of bias. Was the study apparently free of other problems that could put it at a high risk of bias?

For each included study, we described any important concerns we had about other possible sources of bias (for example, whether there was a potential source of bias related to the specific study design or whether the trial was stopped early due to some data-dependent process). We assessed whether each study was free of other problems that could put it at risk of bias as:

- yes; no; or unclear.

If needed, we planned to explore the impact of the level of bias through undertaking sensitivity analyses.

\section{WHAT'S NEW}

\begin{tabular}{lll}
\hline Date & Event & Description \\
\hline 6 February 2017 & Amended & Added external source of support \\
\hline
\end{tabular}




\section{HISTORY}

Protocol first published: Issue 1, 2005

Review first published: Issue 1, 2006

\begin{tabular}{|c|c|c|}
\hline Date & Event & Description \\
\hline 29 April 2016 & New search has been performed & $\begin{array}{l}\text { Search updated in April 2016. There were no new trials that were } \\
\text { eligible for inclusion. New excluded trials added. }\end{array}$ \\
\hline 29 April 2016 & $\begin{array}{l}\text { New citation required but conclusions } \\
\text { have not changed }\end{array}$ & No change to conclusions of the review. \\
\hline 1 May 2015 & New search has been performed & Ms Kwi Moon was added to the authorship of this review \\
\hline \multirow[t]{3}{*}{29 June 2011} & New search has been performed & $\begin{array}{l}\text { This updates the review "One dose per day compared to multi- } \\
\text { ple doses per day of gentamicin for treatment of suspected or } \\
\text { proven sepsis in neonates" published in the Cochrane Database } \\
\text { of Systematic Reviews (Rao 2006). }\end{array}$ \\
\hline & & $\begin{array}{l}\text { Search updated April 2011. No new included trials. New excluded } \\
\text { trials added. }\end{array}$ \\
\hline & & No change to conclusion of review. \\
\hline 29 June 2011 & $\begin{array}{l}\text { New citation required but conclusions } \\
\text { have not changed }\end{array}$ & Dr. Ravisha Srinivasjois added to the authorship of this review. \\
\hline 7 October 2009 & New search has been performed & Converted to new review format. \\
\hline
\end{tabular}

\section{CONTRIBUTIONS OF AUTHORS}

\section{Contributions for the current version of the review (2016)}

Kwi Moon (KM) performed the literature search, identified potential studies (subsequently excluded), reassessed risk of bias of included trials, updated the table of excluded studies, and updated the risk of bias figures, the 'Summary of findings' table and the discussion.

Shripada Rao (SR) conducted an independent literature search, assessed the potential studies for inclusion/exclusion (all subsequently excluded) and edited the new version of the review.

Ravisha Srinivasjois (RS) conducted an independent literature search, assessed the potential studies for inclusion/exclusion (all subsequently excluded) and reviewed the new version of the review.

\section{Contributions for the previous versions of the review $(2006,2011)$}

Shripada Rao (SR) framed the questions for the protocol, wrote the protocol, performed the literature search, selected relevant studies, assessed the methodological quality of studies, checked the data entered into RevMan by Mohamed Ahmed (for the original review), corresponded with authors of the studies to get additional information, wrote the review and compiled other references. SR was also responsible for all the above activities for the updated review.

Mohamed Ahmed (MA) was involved in data entry and analysis.

Ravisha Srinivasjois (RS) performed the literature search and assessed the eligibility of the studies for inclusion/exclusion, and added additional references for the updated review (2011).

Ronald Hagan $(\mathrm{RH})$ revised and edited the drafts of the protocol, provided guidance in selecting outcomes of interest and edited the manuscripts. 


\section{DECLARATIONS OF INTEREST}

One of the review authors (RH) for the previous version is also the investigator of one of the included studies (Hagan 2002).

\section{SOURCES OF SUPPORT}

\section{Internal sources}

- Princess Margaret Hospital for Children, Perth, Australia.

- The Canberra Hospital, Australia.

- Royal North Shore Hospital, NSW, Australia.

\section{External sources}

- Eunice Kennedy Shriver National Institute of Child Health and Human Development, National Institutes of Health, Department of Health and Human Services, USA.

Editorial support of the Cochrane Neonatal Review Group has been funded with Federal funds from the Eunice Kennedy Shriver National Institute of Child Health and Human Development National Institutes of Health, Department of Health and Human Services, USA, under Contract No. HHSN275201600005C

- National Institute for Health Research, UK.

Editorial support for Cochrane Neonatal has been funded with funds from a UK National Institute of Health Research Grant (NIHR) Cochrane Programme Grant (13/89/12). The views expressed in this publication are those of the authors and not necessarily those of the NHS, the NIHR, or the UK Department of Health.

\section{DIFFERENCES BETWEEN PROTOCOL AND REVIEW}

We added the methodology and plan for 'Summary of findings' tables and GRADE recommendations, which were not included in the original protocol or in the original review.

\section{INDEX TERMS}

\section{Medical Subject Headings (MeSH)}

Anti-Bacterial Agents [*administration \& dosage] [adverse effects] [pharmacokinetics]; Drug Administration Schedule; Gentamicins [*administration \& dosage] [adverse effects] [pharmacokinetics]; Hearing [drug effects]; Kidney [drug effects]; Randomized Controlled Trials as Topic; Sepsis [ ${ }^{\star}$ drug therapy] [metabolism]

\section{MeSH check words}

Humans; Infant, Newborn 